\title{
IMMEDIATE AND BEAUTIFUL EFFECTS
} SECURED BY

\section{LARGE TREE MOVING}

\section{Examples of Work Executed}

\author{
BY \\ LEWIS \& VALENTINE CO. \\ ROSLYN, LONG ISLAND
}




\section{LEWIS \& VALENTINE'S GROWING BUSINESS}

\section{BOXWOOD DEPARTMENT}

e beg to submit in the following pages photographs of some work on the largest and finest estates in this country. We how you many more of these if we had the space. Since it annual booklet was prepared every department of our ss has grown.

\section{TREE MOVING DEPARTMENT.}

ur Tree Moving Department is the largest and best equipany tree-moving organization in the world. We have a umber of patented steel tree movers that move trees of any shape.

ur latest steel tree-moving machines make large tree movsafe and certain as is the moving of small trees. The and builders of large private country estates no longer wait le trees to grow. They plant about their new house some rees which produce matured landscape effects immediately. estment in the building of the home pays better than does oney expended for some large shade trees that will tower the house line, giving the house a dignified setting and lendportance to the place they occupy.

ne or more of our tree-moving machines are permanently led in several of the large cities of the Atlantic, Middle and $\mathrm{m}$ states, and the one stationed nearest you could be sent to state promptly no matter where you live. Whether your large or small we will gladly furnish you with an estimate loing any tree moving work you have in mind. Our prices lowest consistent with the best quality of work. Our repatives have made a careful search of the good specimen Maples, Pin Oaks, and other native trees growing in the y near most of the important eities in the East and Middle We have a list of the available trees in your vicinity and if e interested in transplanting to your estate some of the finest rees, now growing in your vicinity, let us select from among $t$, some of the best trees growing near you and let us take see them. Then we could give you an estimate upon $g$ such of them as you like to your property, with our usual f guarantee that they will live.

Our Boxwood Department is the most extensive organization in America, for finding and collecting old English Boxwood plants. These Boxwood plants are from 50 to 200 years old. We could supply you with any age, size and shape plants that you may require, and we would be glad to mail to you photographs of some of our large collection of Box:

The large volume of our trade in Boxwood plants makes it possible for us to find them at the least expense, to buy them at the lowest prices and to sell them at a minimum of profit. We can offer you the best available in old Boxwood plants at the lowest market prices.

\section{ROAD BUILDING DEPARTMENT}

Our Road Building and Grading Department employs the most efficient road builders to be found. We have built many of the finest roads existing on private country estates. Our estimator will gladly visit your property without charge to you and estimate upon the cost of constructing whatever kind of road you require. Much of our road building and grading work we do at actual cost of the work plus $15 \%$ for our services. By having this work done on a percentage basis, you are free from time to time to change your specifications, increasing or decreasing the amount of work, and we find that in most cases the owner is better satisfied by having his grading done and his road built on percentage than by contracting the work.

\section{CEDAR TREE DEPARTMENT}

Our Cedar Tree Department, ship Cedar trees, from 6 to 30 feet in height, to points as far south as Richmond, Va., and as far west as St. Paul, Minn. We have the largest collection of Cedar trees (Juniperus Virginiana), of all sizes, in the East.

\section{NURSERY, DEPARTMENT}

Our Nursery Department offers a large variety of choice nursery stock growing in our nurseries at East Rockaway and at Roslyn, N. Y. We have collected the best material available from many other nurseries, and we can offer you exceptional facilities for putting you in touch with just the species and sizes of plants you may require. 


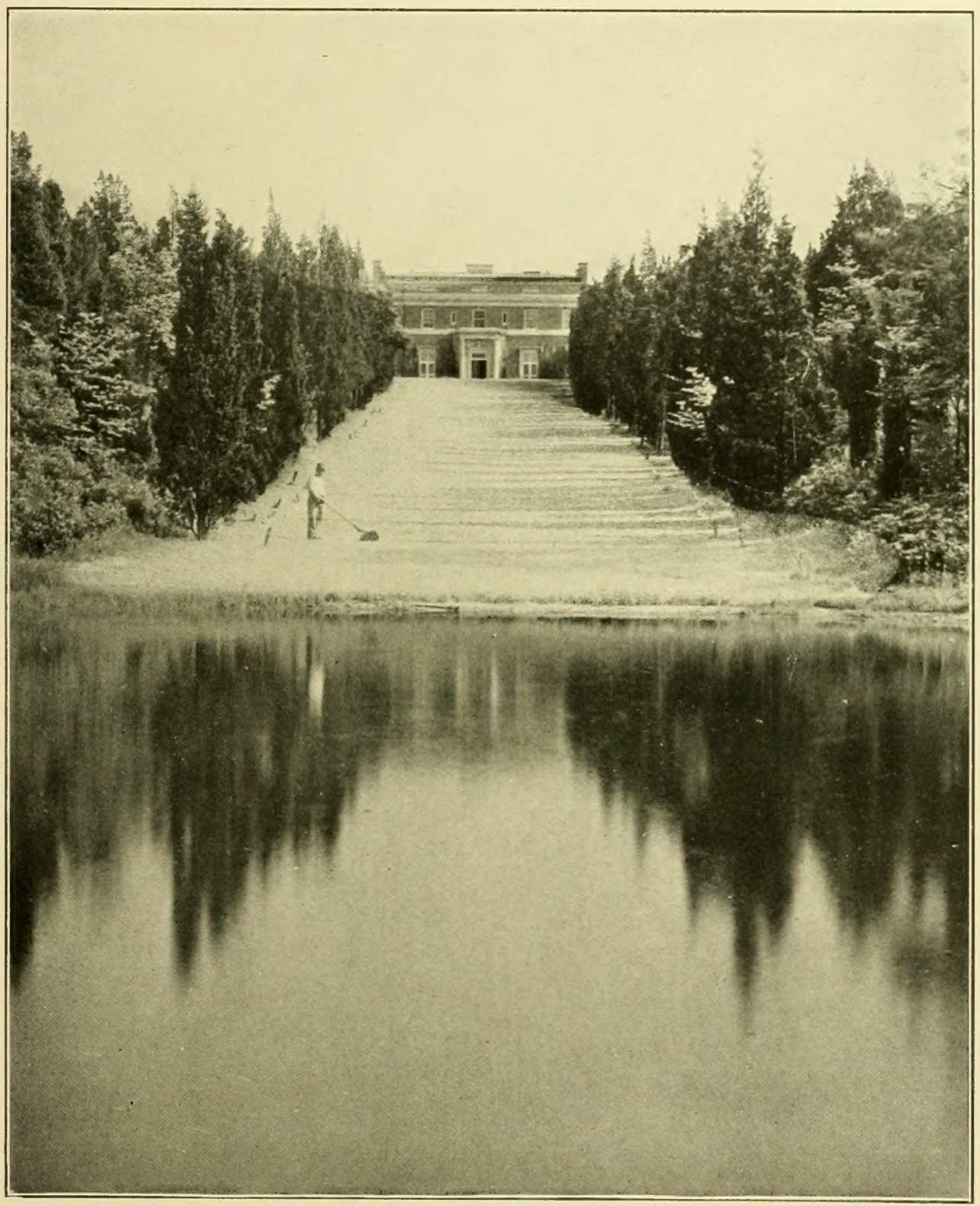

\section{LEWIS \& VALENTINE}

MAIN OFFICE AND NURSERY ROSLYN, L. I., N. Y.

TELEPHONE : ROSLYN 256 - 257

BRANCH NURSERY

EAST ROCKAWAY, L. I.

TELEPHONE: LYNBROOK 751-W

New York Office

150 Nassau Street

New York

Tel. Beekman 3514
Boston

33 Statio

Brookline

Tel. Brookli
Philadelphia and Wilmington

722 French Street, Wilmington, Del. Tel. Wilmington 4153-W

We have tree moving apparatus permanently locat Cambridge, Mass.; Hartford and New London, C Westchester County, N. Y.; Philadelphia, Wilmin Baltimore, Washington, Cleveland, and Chi 


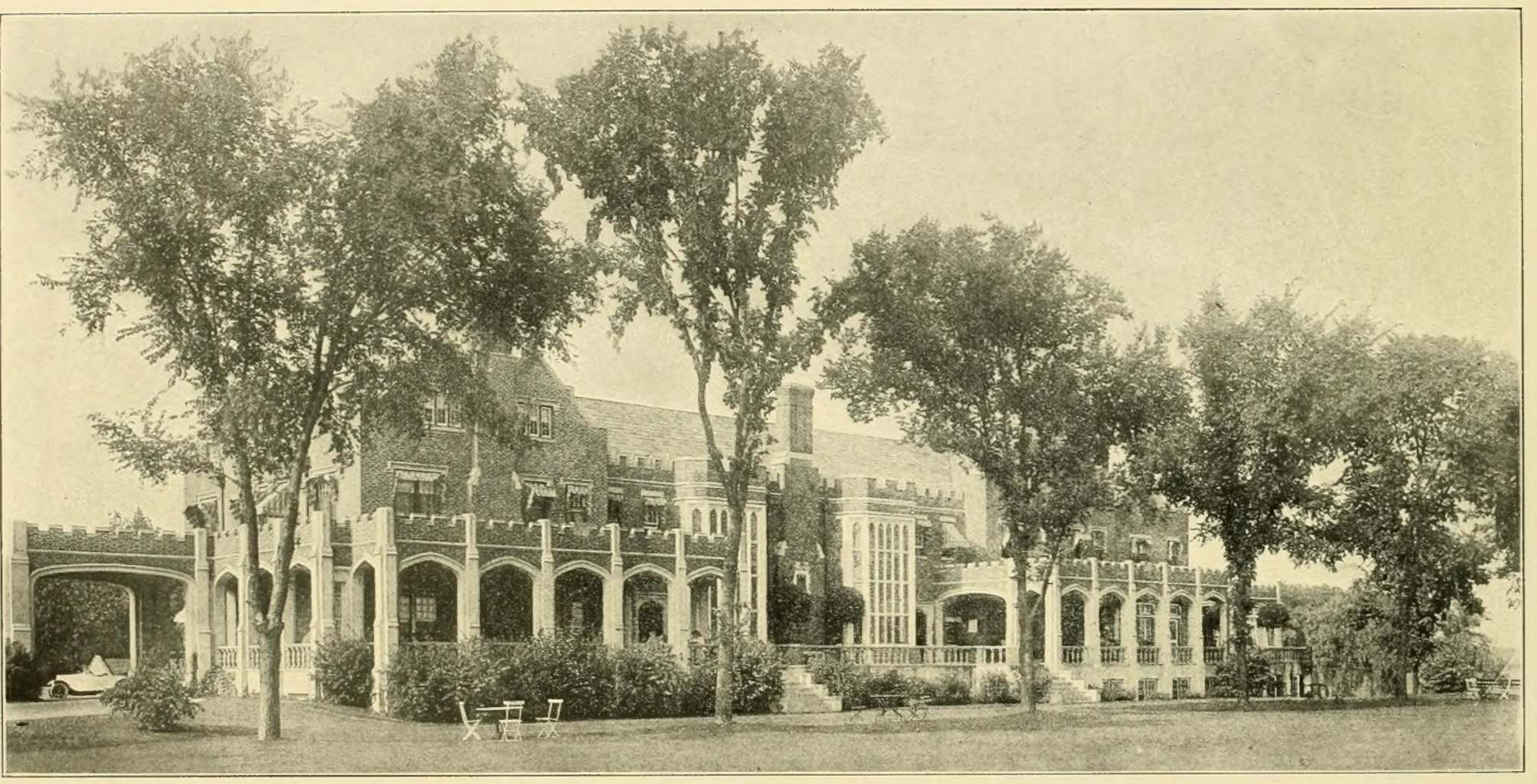

Nassau Country Club, Glen Cove, Long Island. These Elms, 50 to 60 feet high, were moved on our patented tree moving machines and by our skilled workmen, and the result is a uniform planting of dense foliaged trees that do not know they have been moved. It is wise to use Elms or other high branched trees near the residence to prevent shutting out the breeze and the view. The demand for our patented device for moving trees has grown so rapidly that it has required us to manufacture 30 machines and to maintain a force of 100 skilled workmen to operate them. We can supply you with one or more of these machines or one or more skilled workmen to cooperate with your own teams and laborers, or we will contract the work. If you have trees too close together, you should move some of them to permit the remaining ones to develop. By moving big trees you save a lifetime of waiting. If you want immediate effects and have no large trees available, we would be glad to supply you with a man to locate trees in your vicinity suitable for moving and submit photographs of the available trees to you, together with an estimate for moving them to your property.

\section{(C) 1.4445304}

\section{OCT 241916}




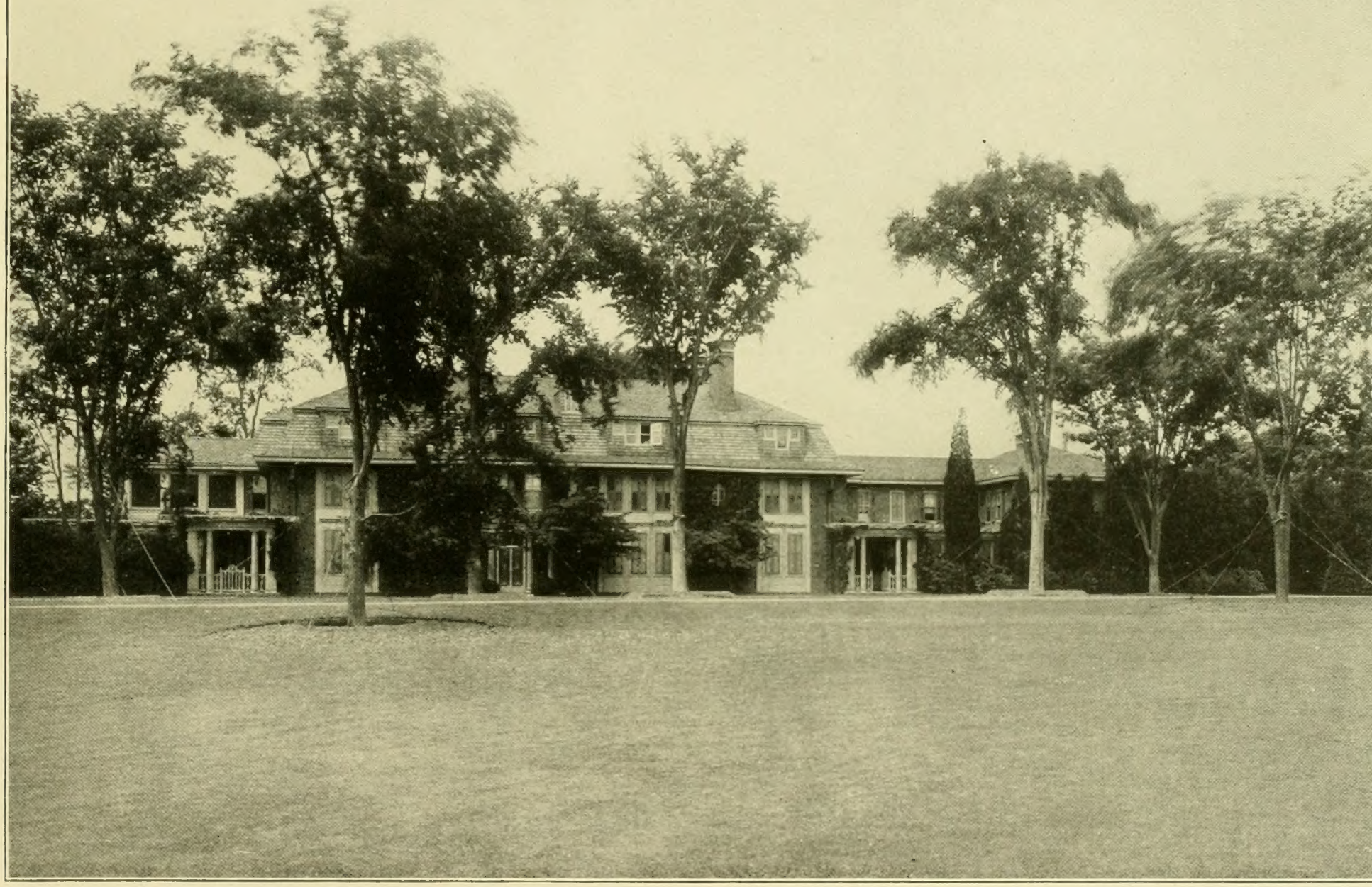

Estate of Mrs. Harold I. Pratt, showing large Elms, several of them over 2 feet in diameter and over 70 feet high. Moved in on our moving machines. Results of this kind are obtained by moving trees in a careful manner and giving them intelligent care after they are plar James L. Greenleaf, Landscape Architect. 


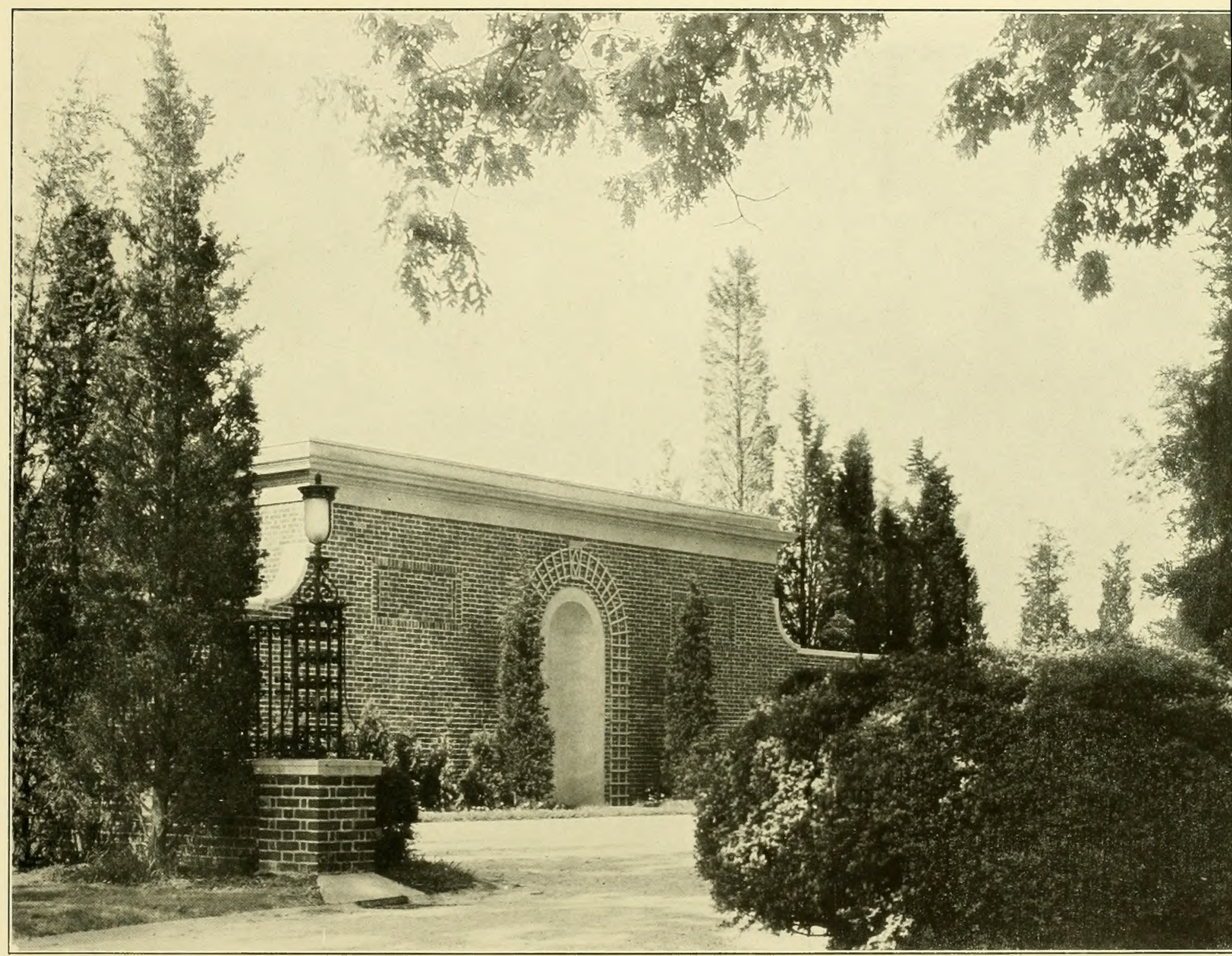

View showing a few of the many Boxwood and Cedars moved by us to the estate of J. Swan Frick, Esq., Baltimore, Md., John Russell Pope, 1 Architect. We have tree moving machines permanently located in every large city, and the manager of our nearest office will give your prol immediate attention. We have undoubtedly the largest and finest stock of Cedar trees and old Boxwood available. We have made a thor canvass of several states and located many of the best specimens of old Boxwoos, and if interested, send for photos of available specimens. We in a position to make the finest Boxwood garden in the country, just having completed the Boxwood plantings for Mrs. A. S. Burden, Mrs. C Rumsey, Mrs. James A. Burden, Jr., Victor Morawetz, Esq., Bradley Martin, Esq., Alfred I. du Pont, Esq., Eugene du Pont, Esq., and many other 


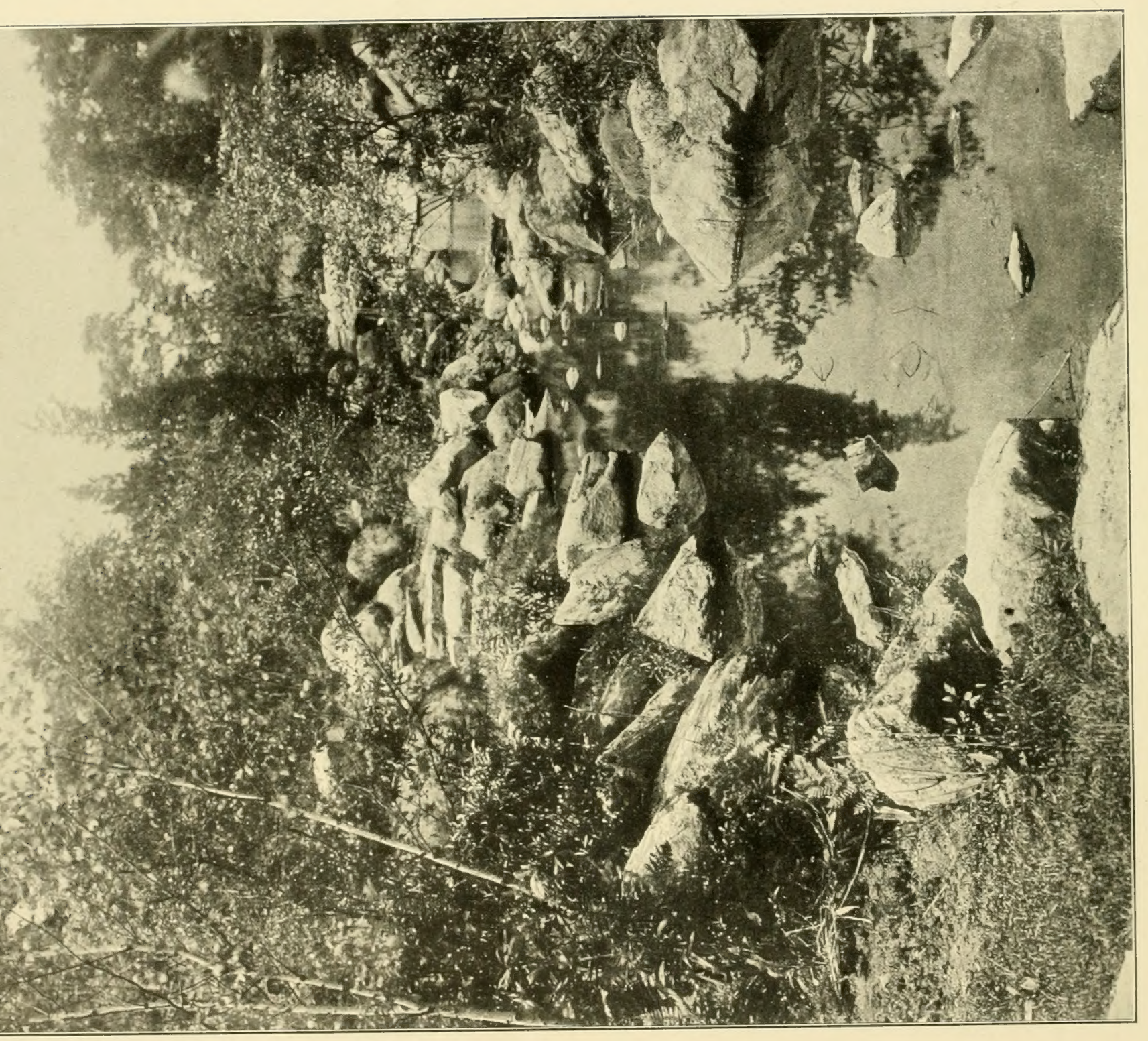

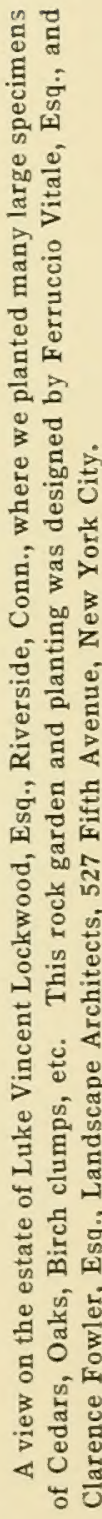




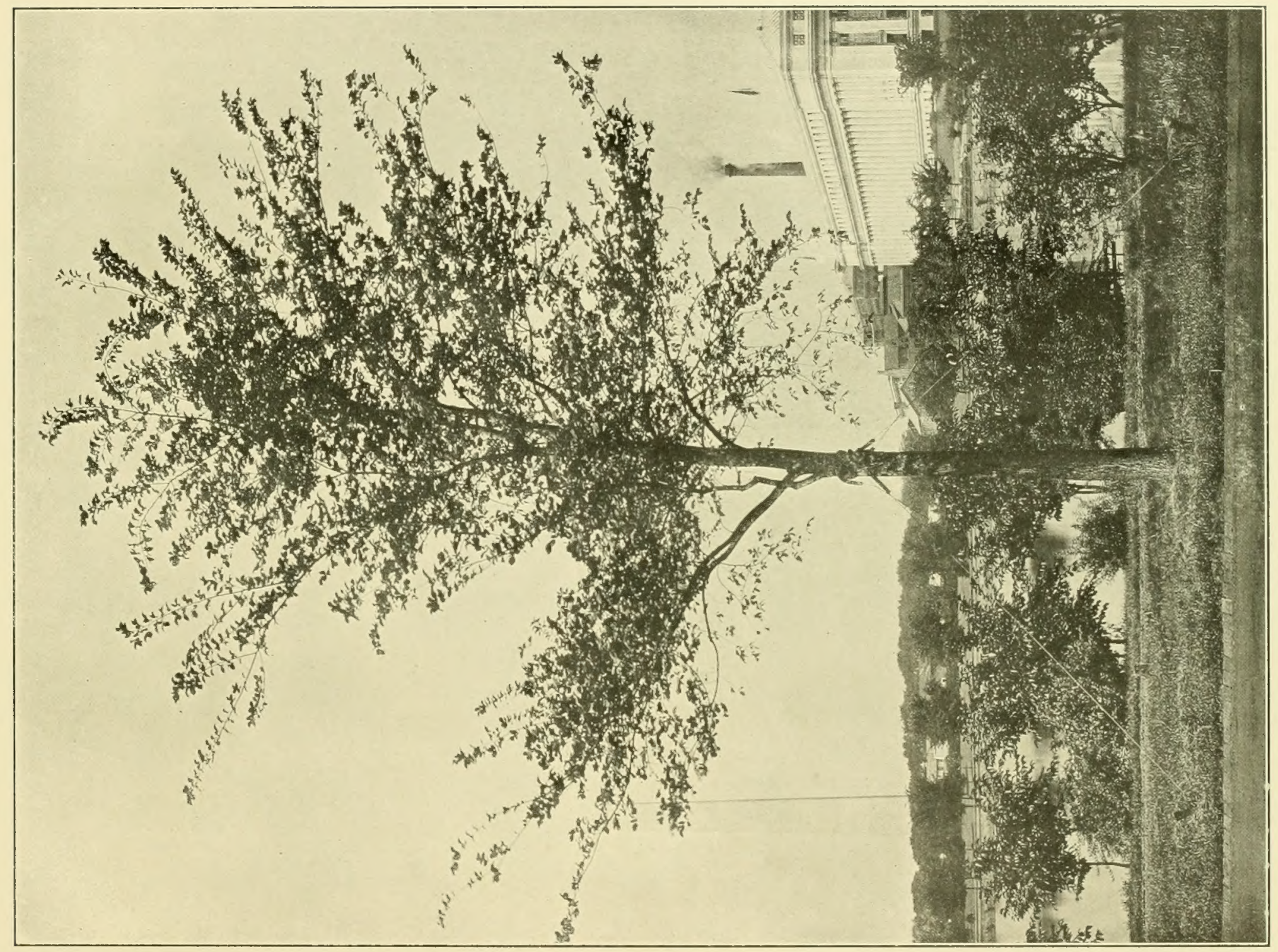




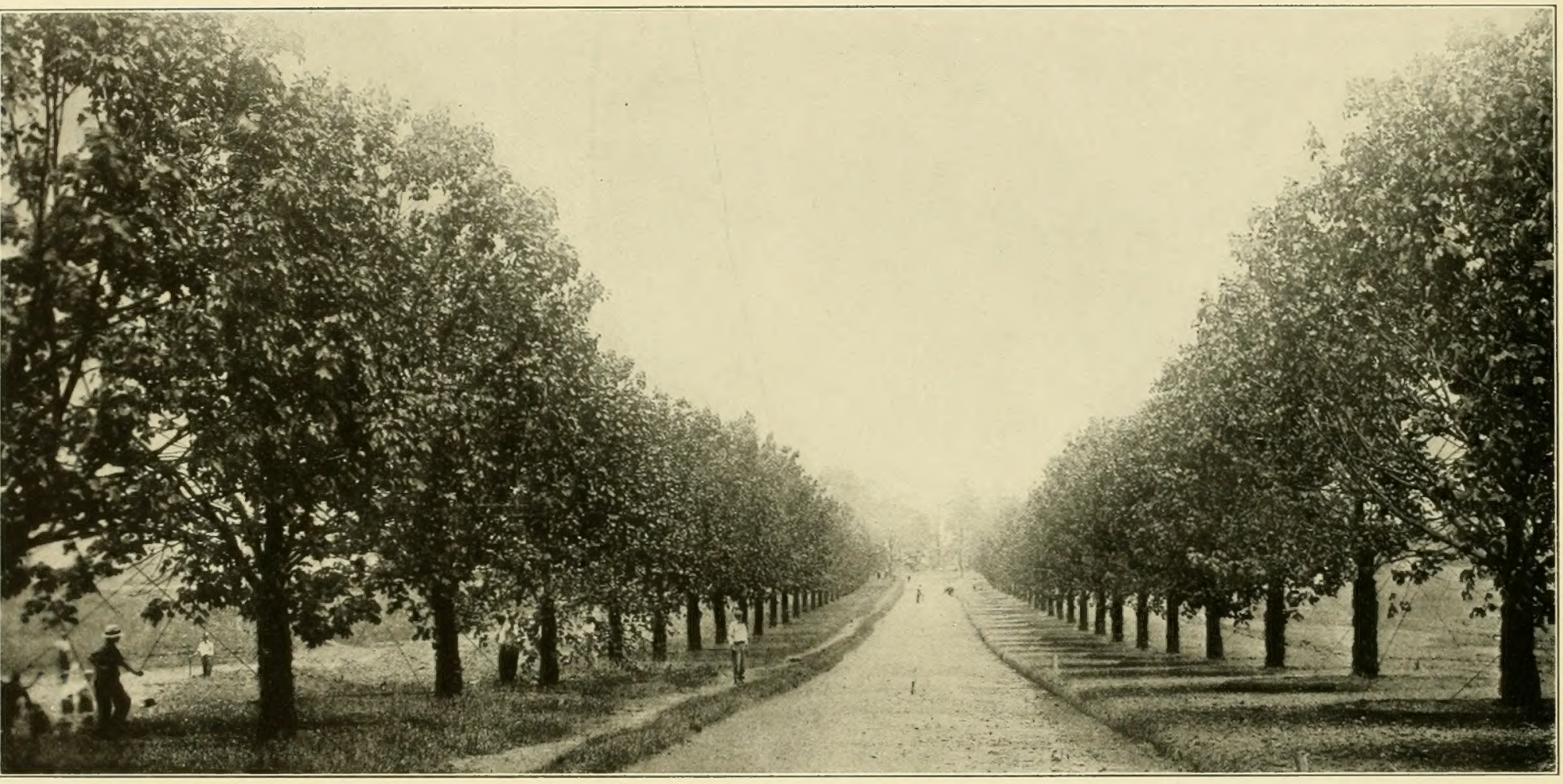

Shows the Estate of Otto H. Kahn, Esq., Messrs. Delano \& Aldrich, Architects. Of about 100 large trees, not one tree died, and every tree is in a flourishing condition. Our big trees not only live, but flourish. The reason for this is because our apparatus is so designed as to preserve an immense volume of roots; and our skilled foremen, who we have trained for years, have developed this work into a science. By using our skilled workmen and patented devices the architects have here secured results that would have required a lifetime of waiting for the usual nursery trees to produce. If you will acquaint us with your big-tree problem, we will submit to you a definite proposal of just what we can do for you. 


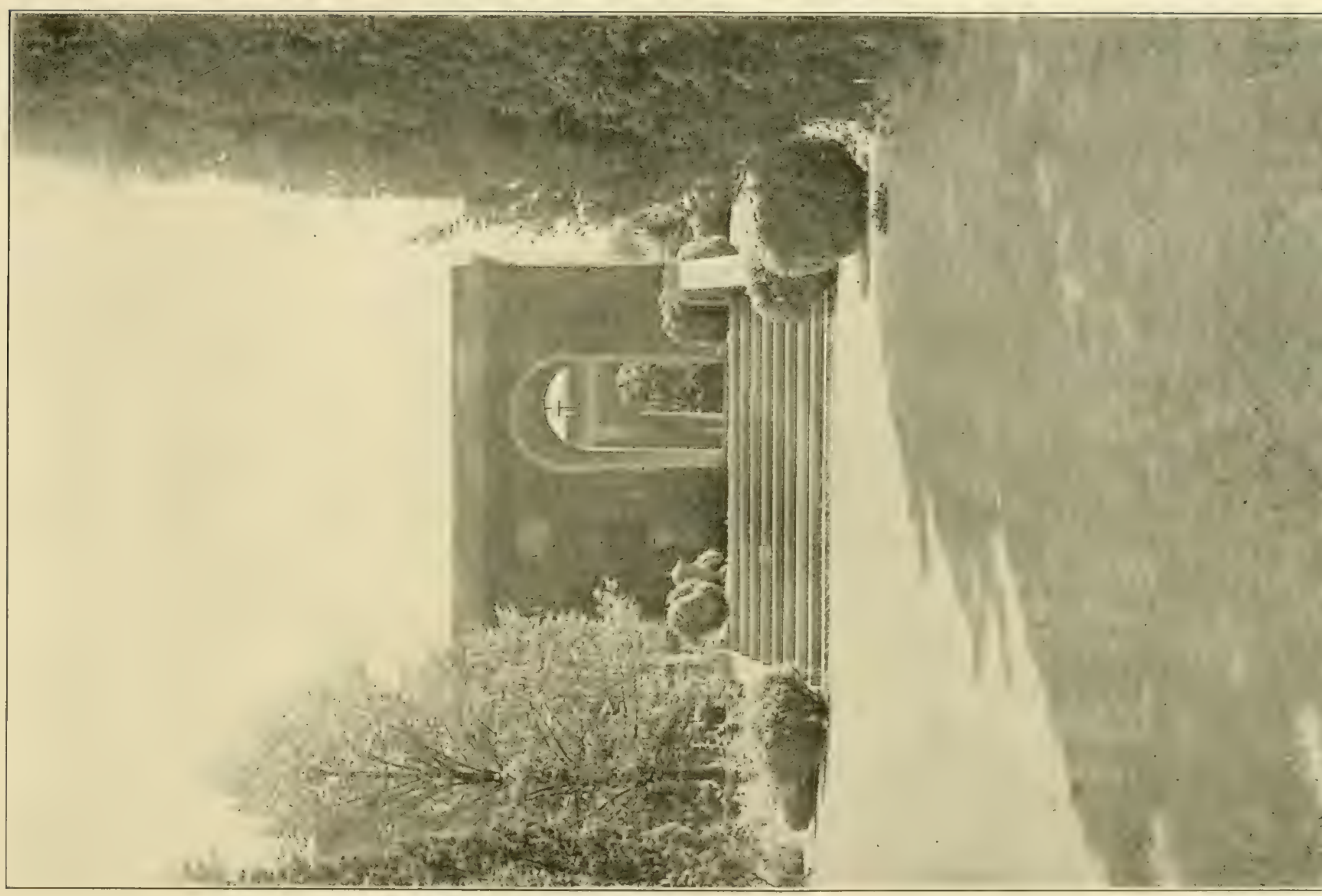




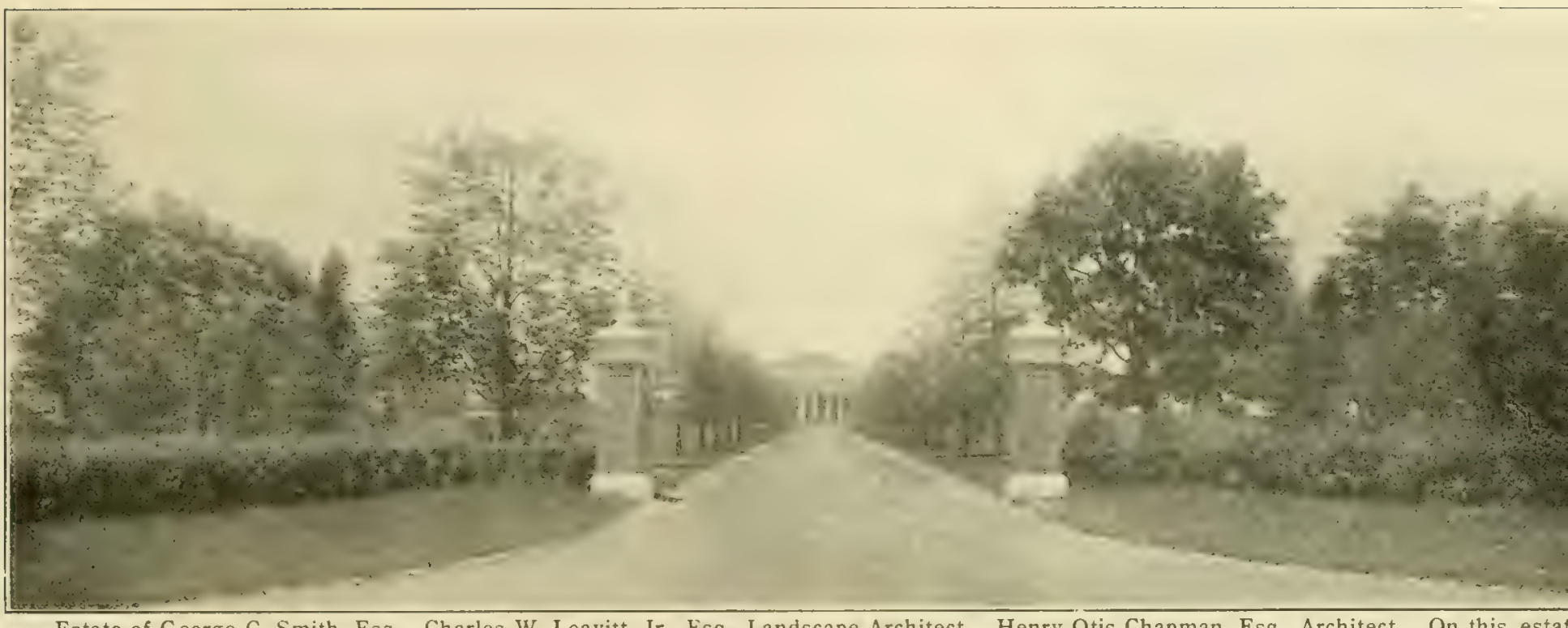

Estate of George C. Smith, Es7. Charles W. Leavitt, Jr., Esq., Landscape Architect. Henry Otis Chapman, Esq., Architect. On this estat did the road building, grading and tree moving. All this work progressing at one time under one of our skilled foremen, was much more econom and efficiently done than if each part had been undertaken by separate contractors. If we do your whole job we assume the responsibility fo finished result in every respect.

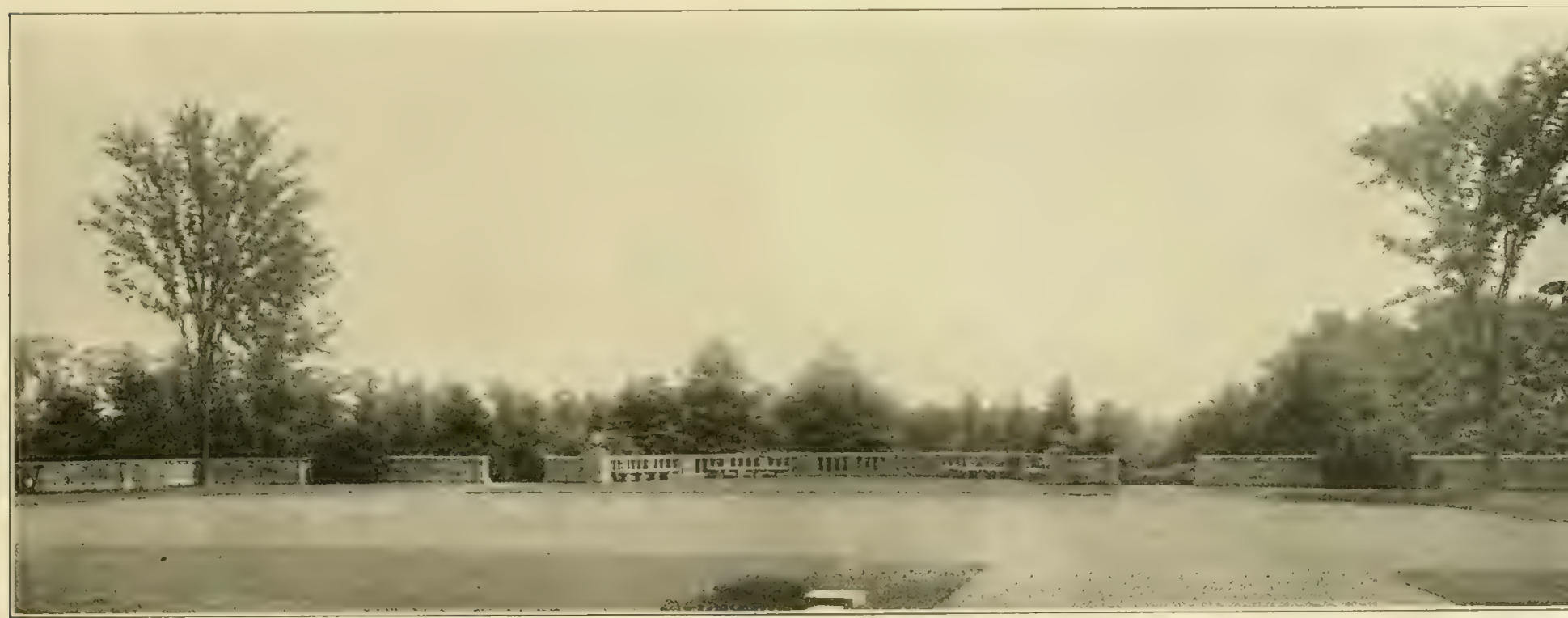

Two of the many large Elms moved by us to the estate of George D. Pratt, Esq., New York State Conservation Commissioner. These Elms f in a charming view and give height to the landscape. Are there not some large Elms in the vicinity of your estate which you would like to hav your property? If you do not know of any we would be glad to locate some large trees for you and submit photographs of them to you, together an estimate for moving them to your property. 


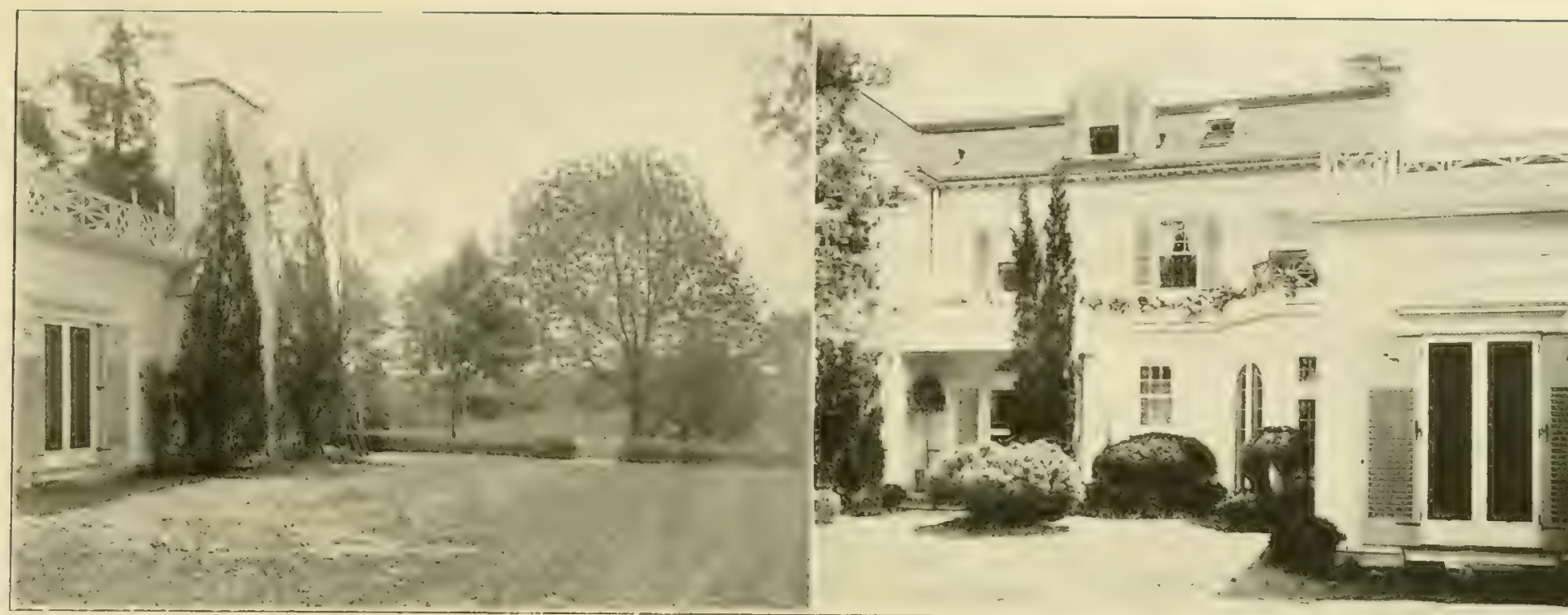

Estate of C. C. Rumsey, Esq., Messrs. Movius \& Rotch, Landscape Architects. Showing a few of our large Maples, Cedars, Boxwood, etc.

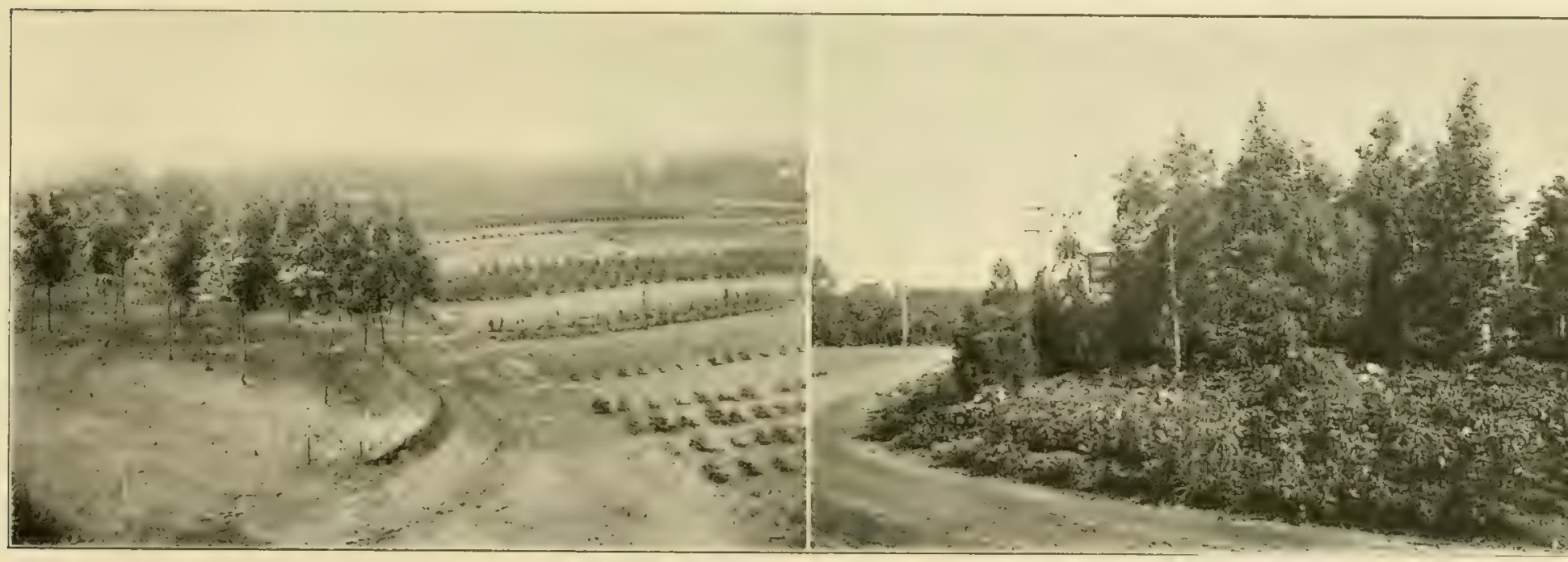

Views in our nursery. We have not only large trees, but nearly a million of the usual size. Most of our nursery stock is supplied to profes buyers and landscape architects, at wholesale prices. If you require nursery stock and will send us a list of your requirements, we will tell you the finest quality of stock will cost. Have you our nursery stock list on file? If not, it is yours for the asking. 


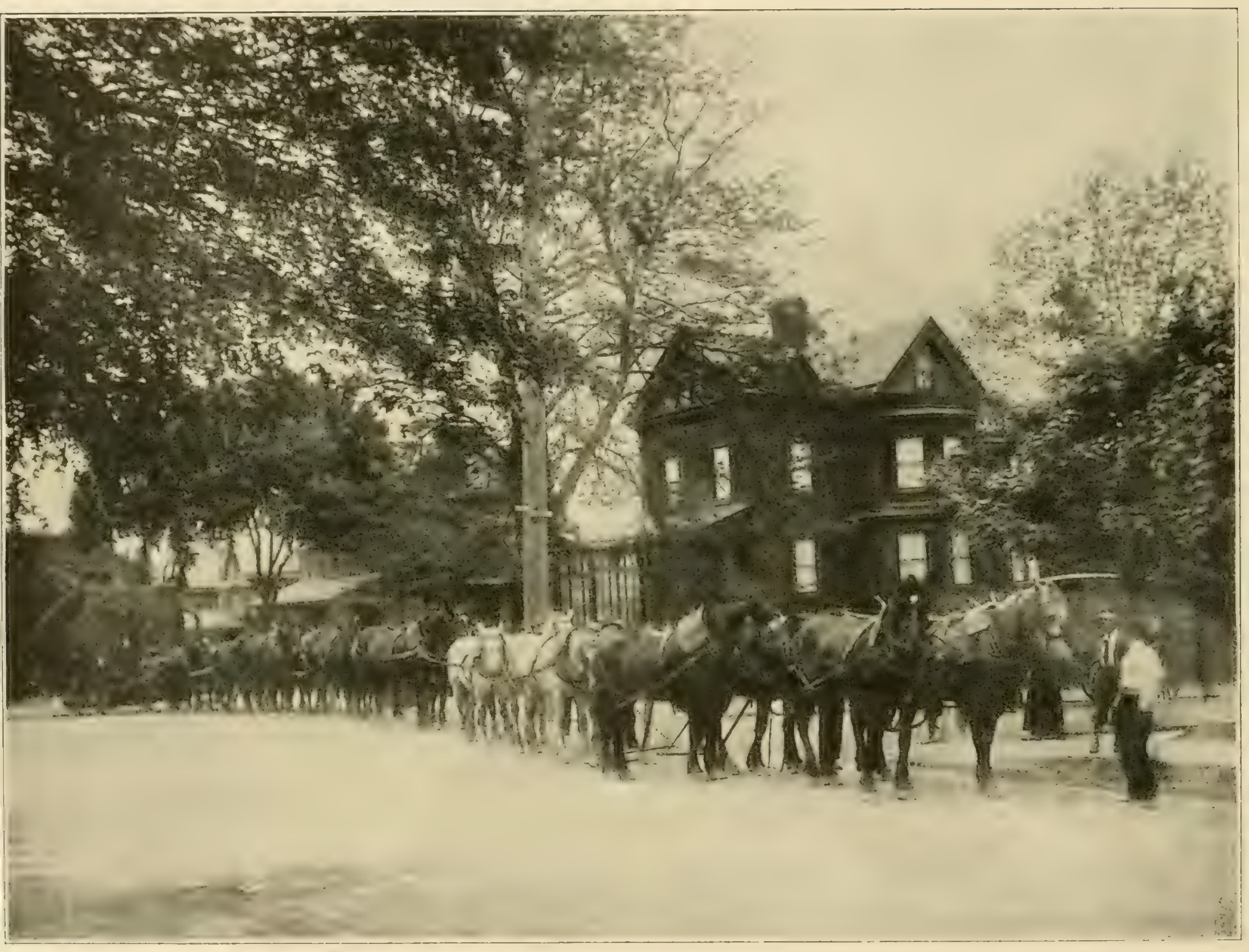

A large Purple Beech moved by us a distance of 15 miles under direction of Ferruccio Vitale, Esq., Landscape Architect for Pierre S. duPont, Esq., Wilmington, Del. This tree with its large ball of earth was moved over exceptionally rough roads. 


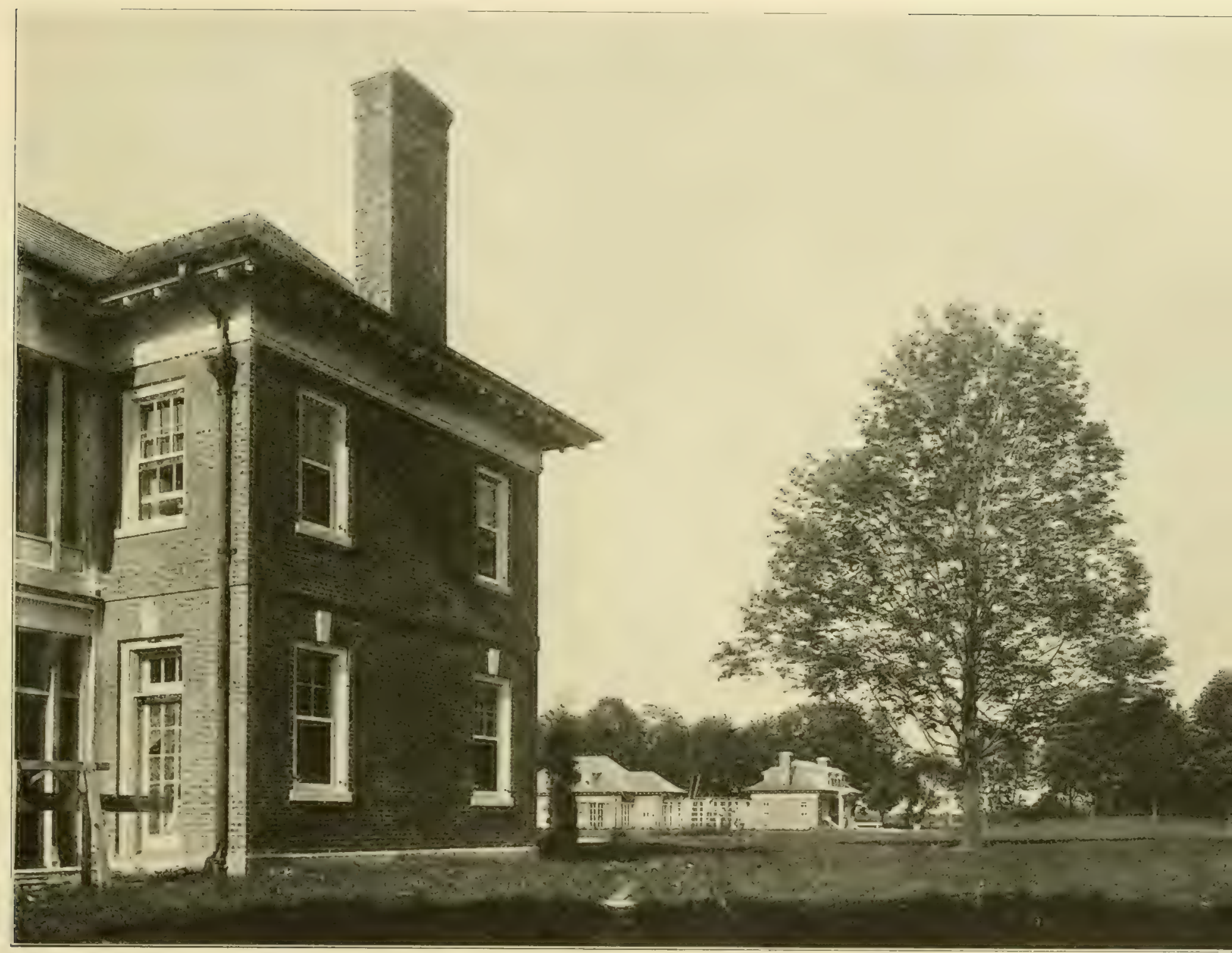

Estate of Mrs. Frederick L. Richards, where we moved many large trees and did the entire landscape work including the grading and construc of the roads, for William Adams, Esq., Architect and Landscape Architect. We have constructed some of the finest roads on Long Island with our la force of men who are trained in this work. Where the tree moving and other landscape work, including the grading and road building, are done at time by one organization much unnecessary expense is thereby saved. 


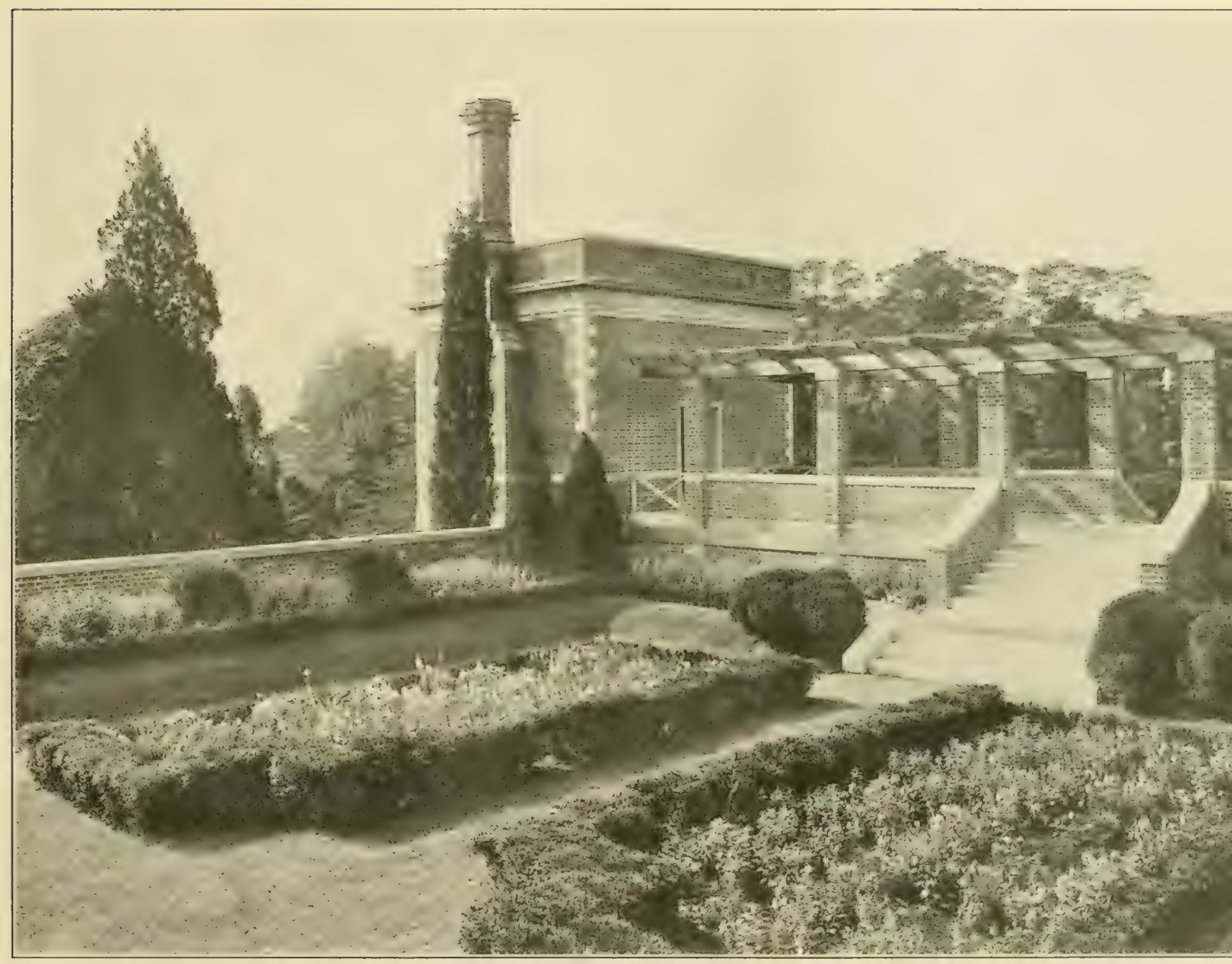

A Boxwood and Cedar planting on the Herbert L. Pratt Estate. James L. Greenleaf. Esł., Landscape Architect. On this estate we moved many trees, without the loss of a single one. 


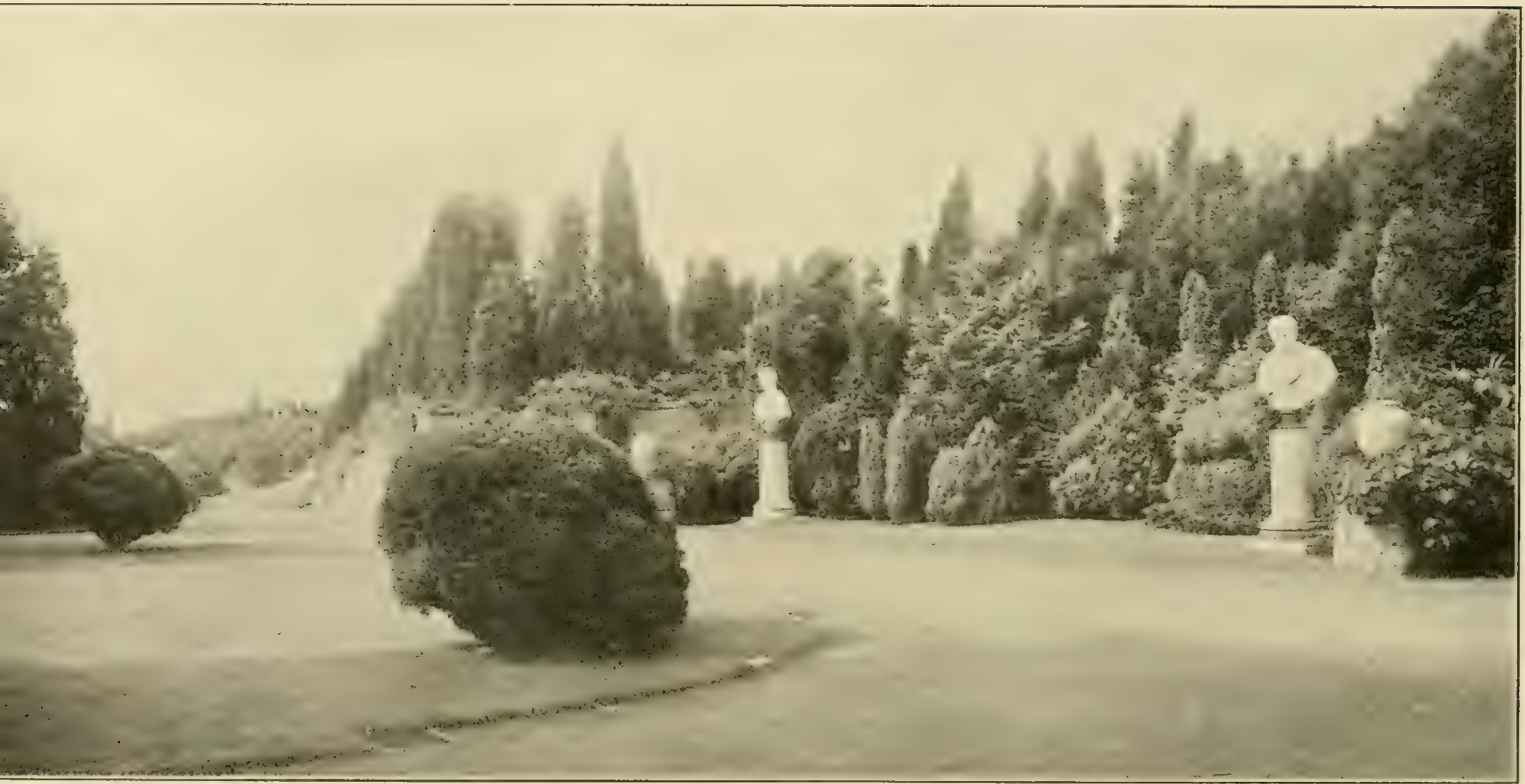

wing striking results produced by the use of large Cedars, Pines, and Old Boxwood. James L. Greenleaf, Esq., Landscape Architect. May we supply you with a few large specimens of old Boxwood like that shown in the foreground? 


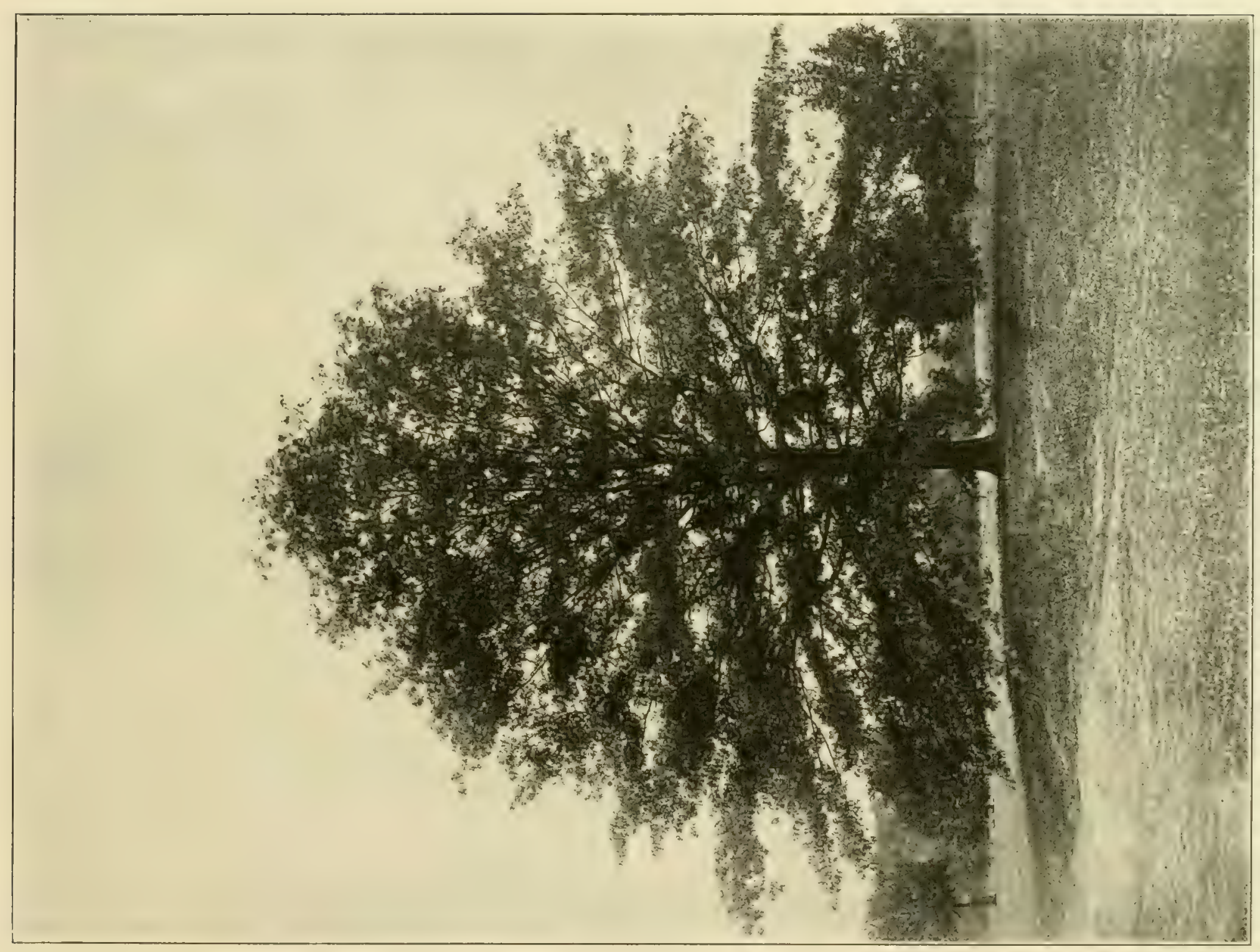




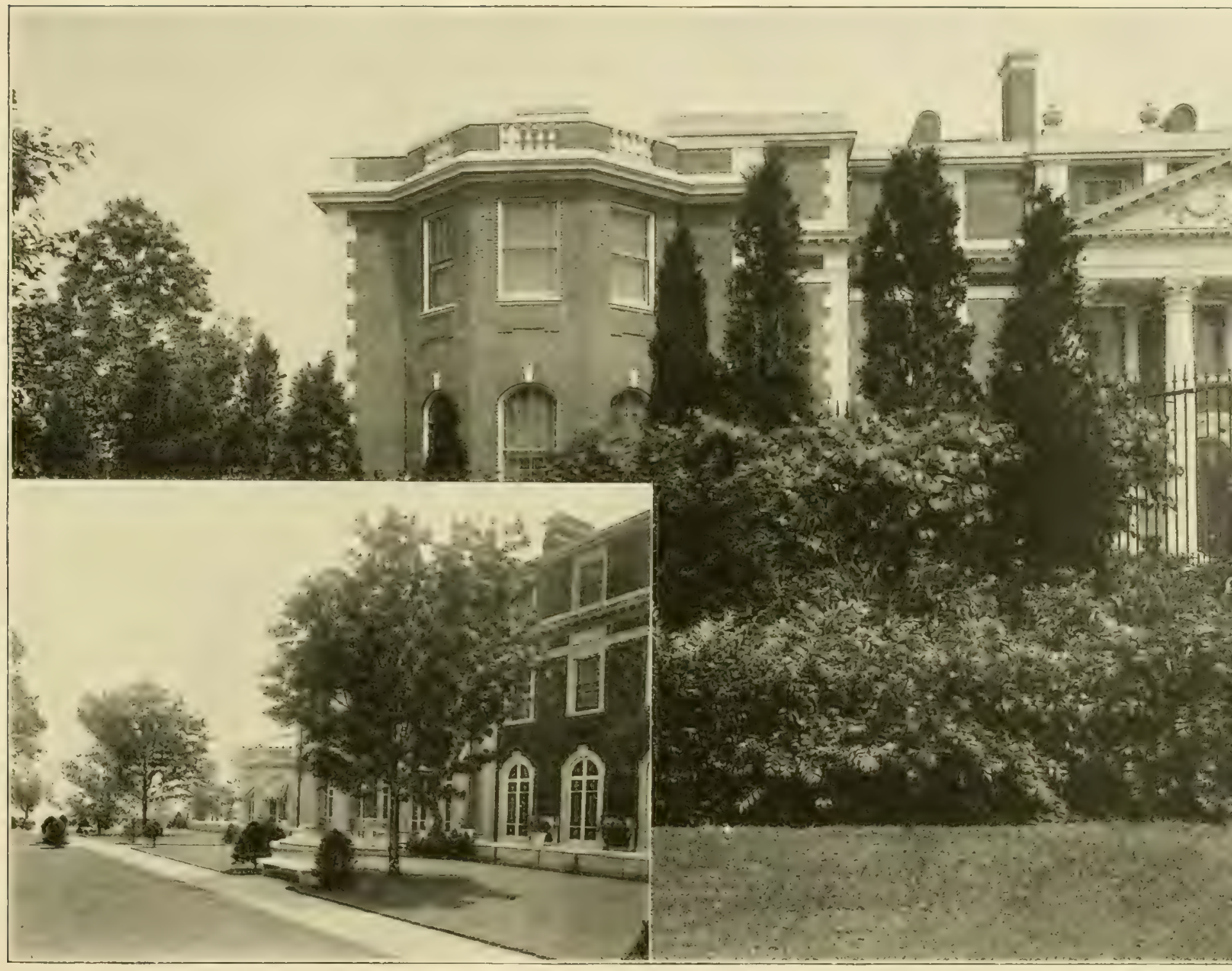

The Ormond G. Smith Estate at Center Island, Oyster Bay, L. I. Ralph M. Weinrichter, Esq., Landscape Architect. Showing a few of the hund large evergreens and shade trees planted from time to time by us on this estate during the past several years. 


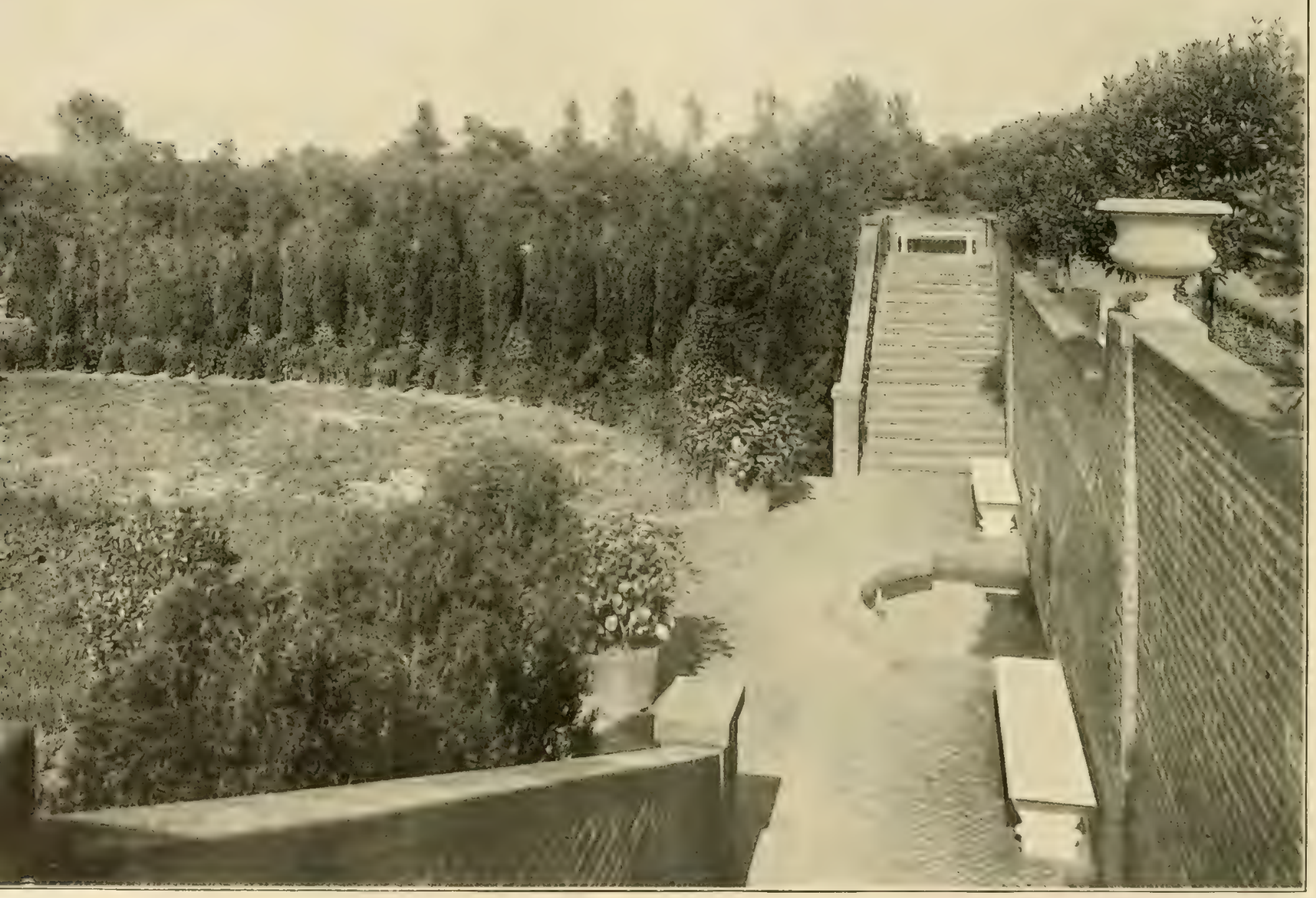

Large evergreens which we planted about the sunken garden on the Estate of Donald Geddes, Esq. 


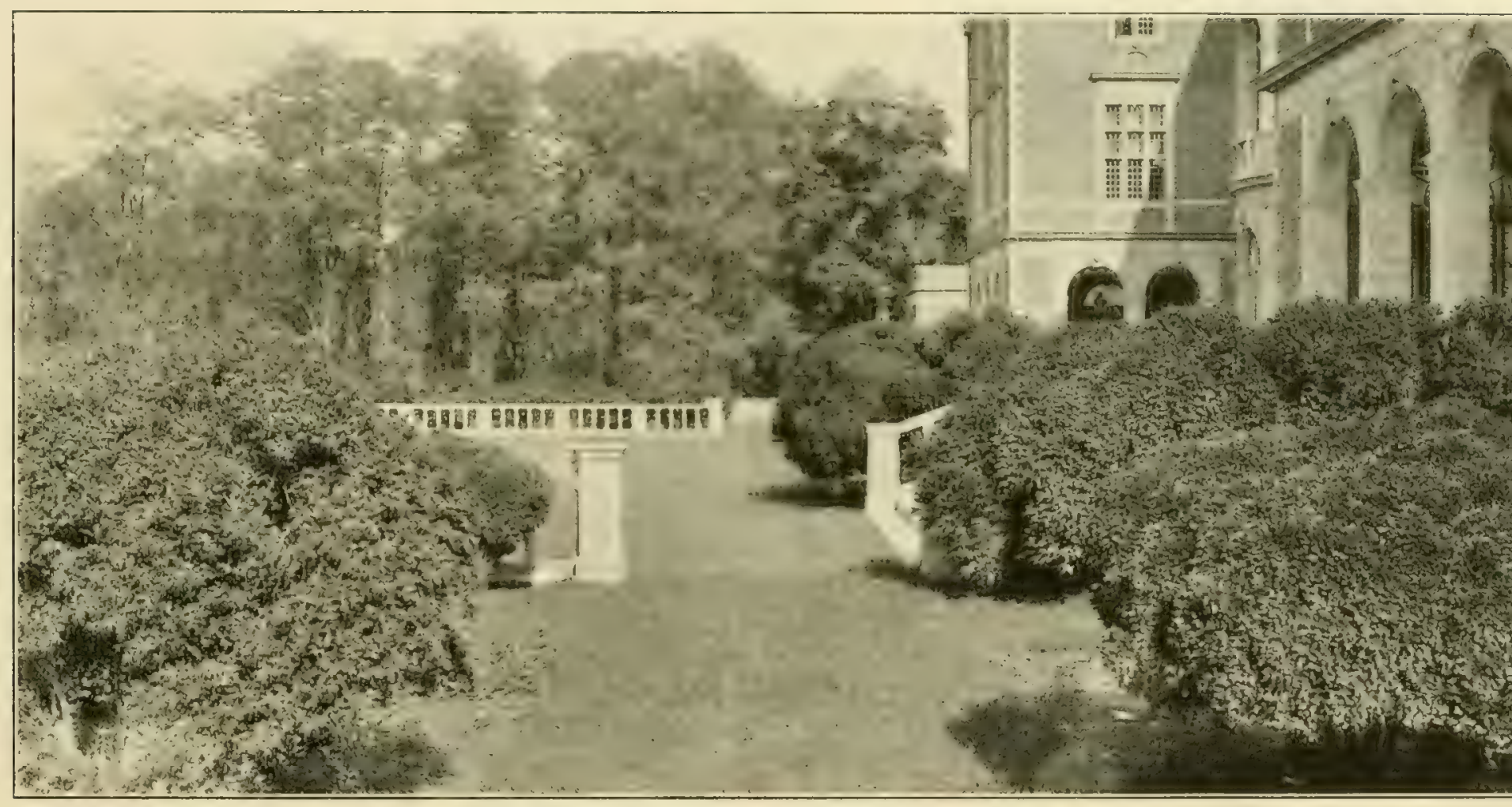

Large Boxwood, planted on the H. L. Pratt Estate, Glen Cove, L. I. James L. Greenleaf, Esq., Landscape Architect. A few old Boxwoo mens in your garden lend an air of age and dignity that cannot be produced with any other material. May we send you photographs of som from which you can select? 


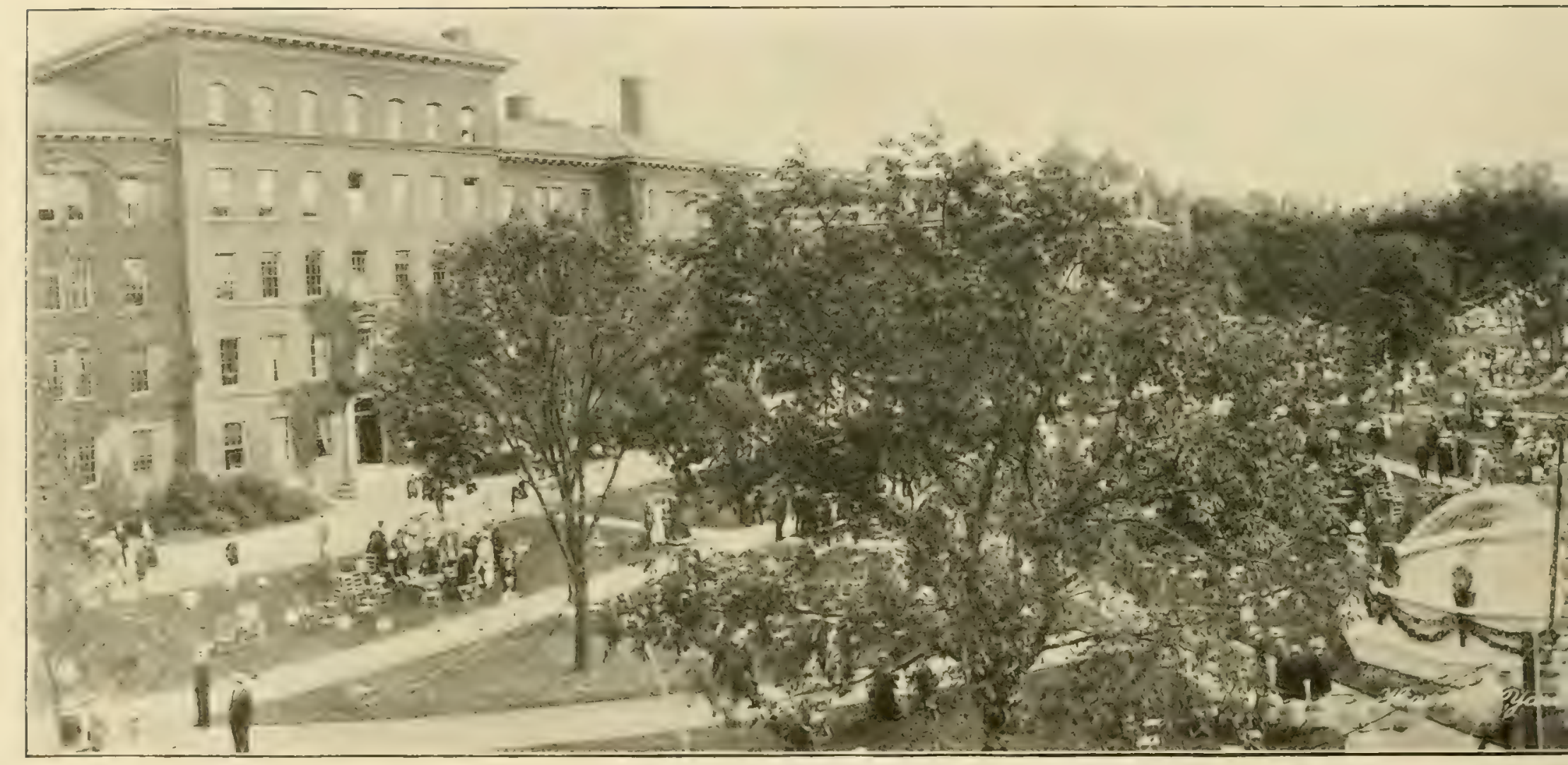

Harvard Yard. Several years ago the elm-leaf beetle killed most of the large historic Elms in the Harvard Yard, and we were employed to replace them with nur tree moving machines and skilled workmen. The photograph above shows the results we obtained the first year after planting. Any one recently acquainted 


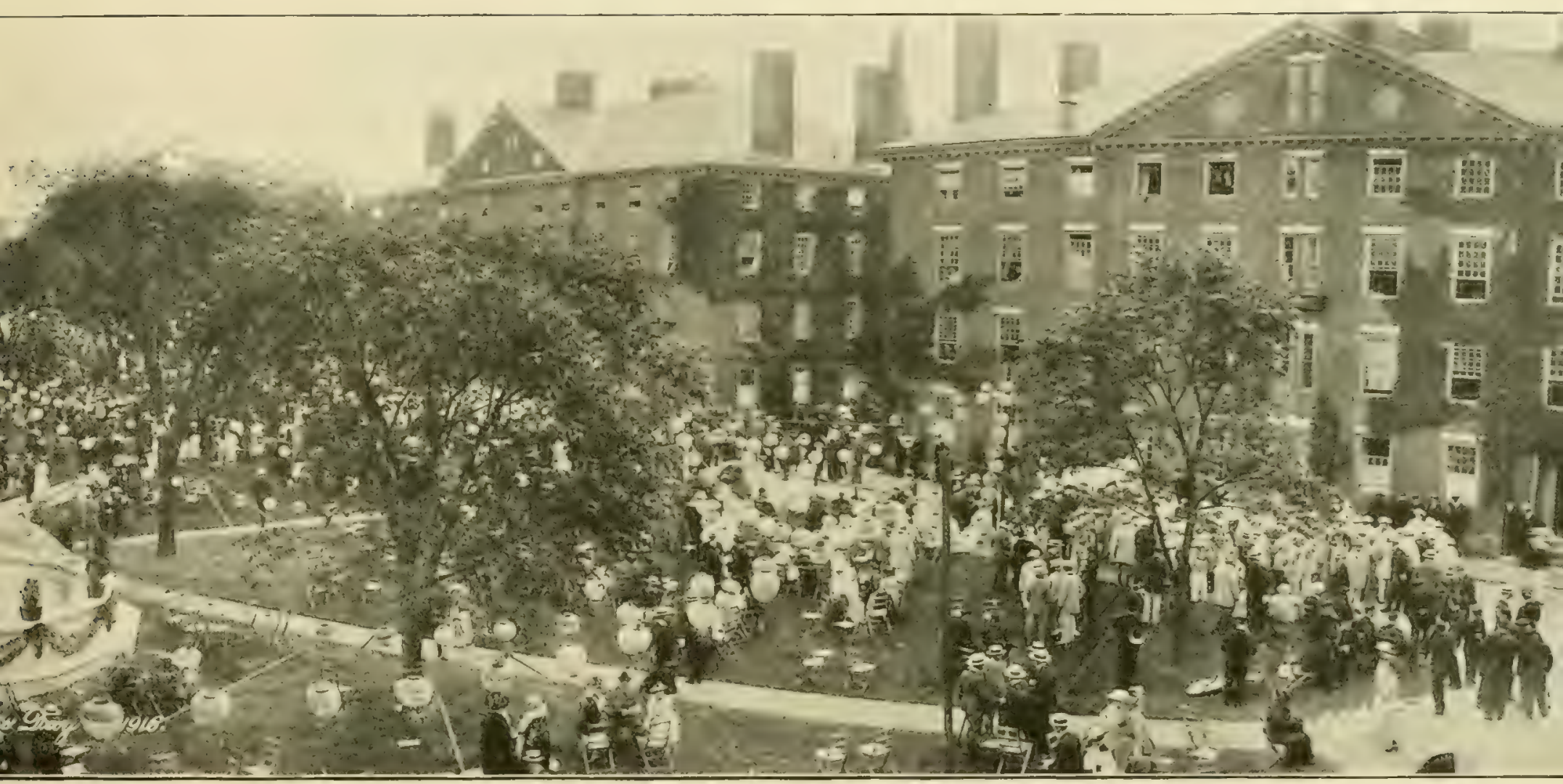

with the Harvard Yard knows the wonderful transformation produced by our big tree moving. This work was carried on under the direction of Prof. R. F. Fis of the University, and the trees were presented by Arthur H. Lea, Esq., of Philadelphia. 


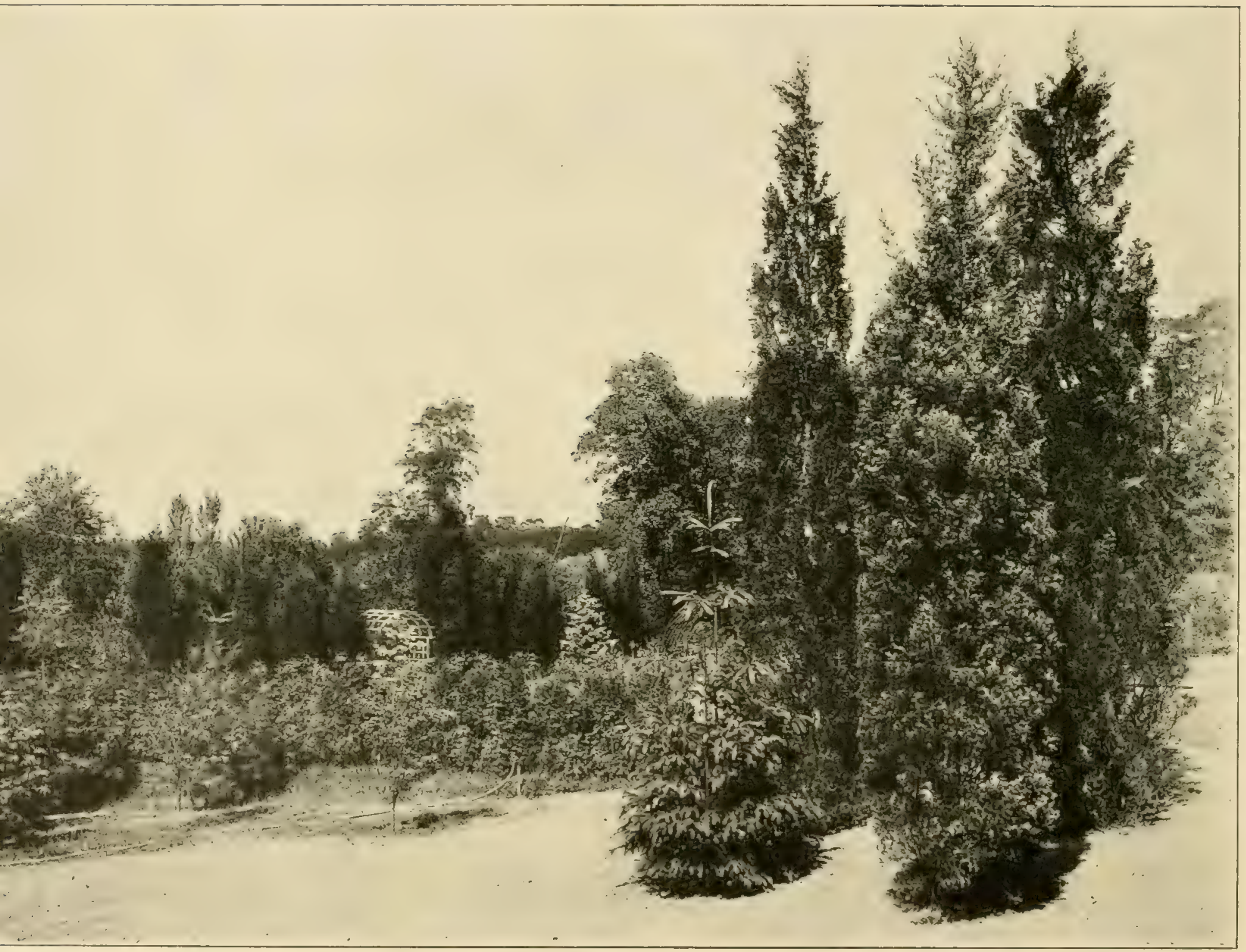

Immediate effect produced in the garden of Mrs. William Beard by using a few of our large evergreens. 


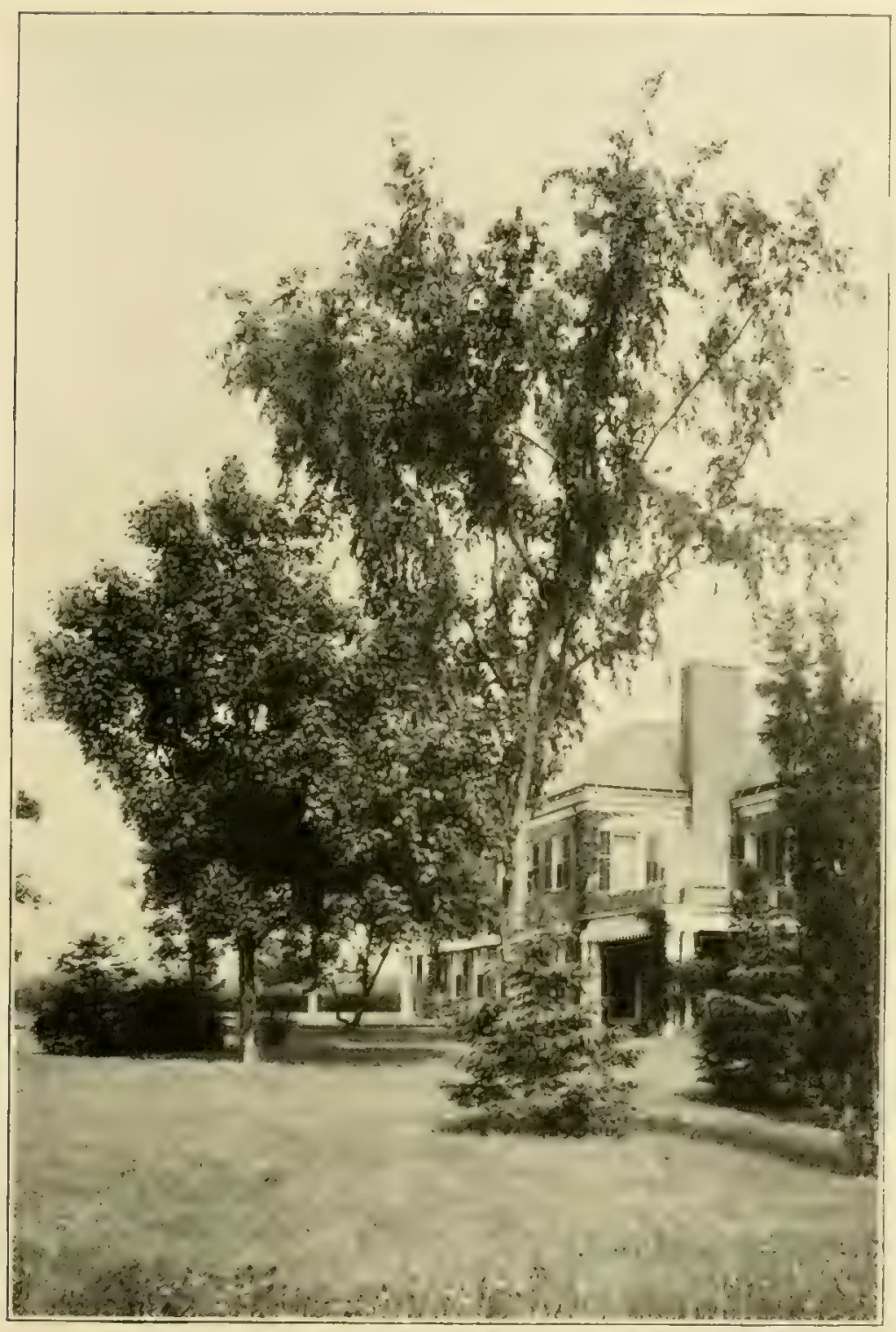

Estate of Julian Ripley, Esq., showing a view of large Maples, Elms, etc., planted about the residence. Small trees planted near the house fail to give the house a mature and homelike atmosphere.

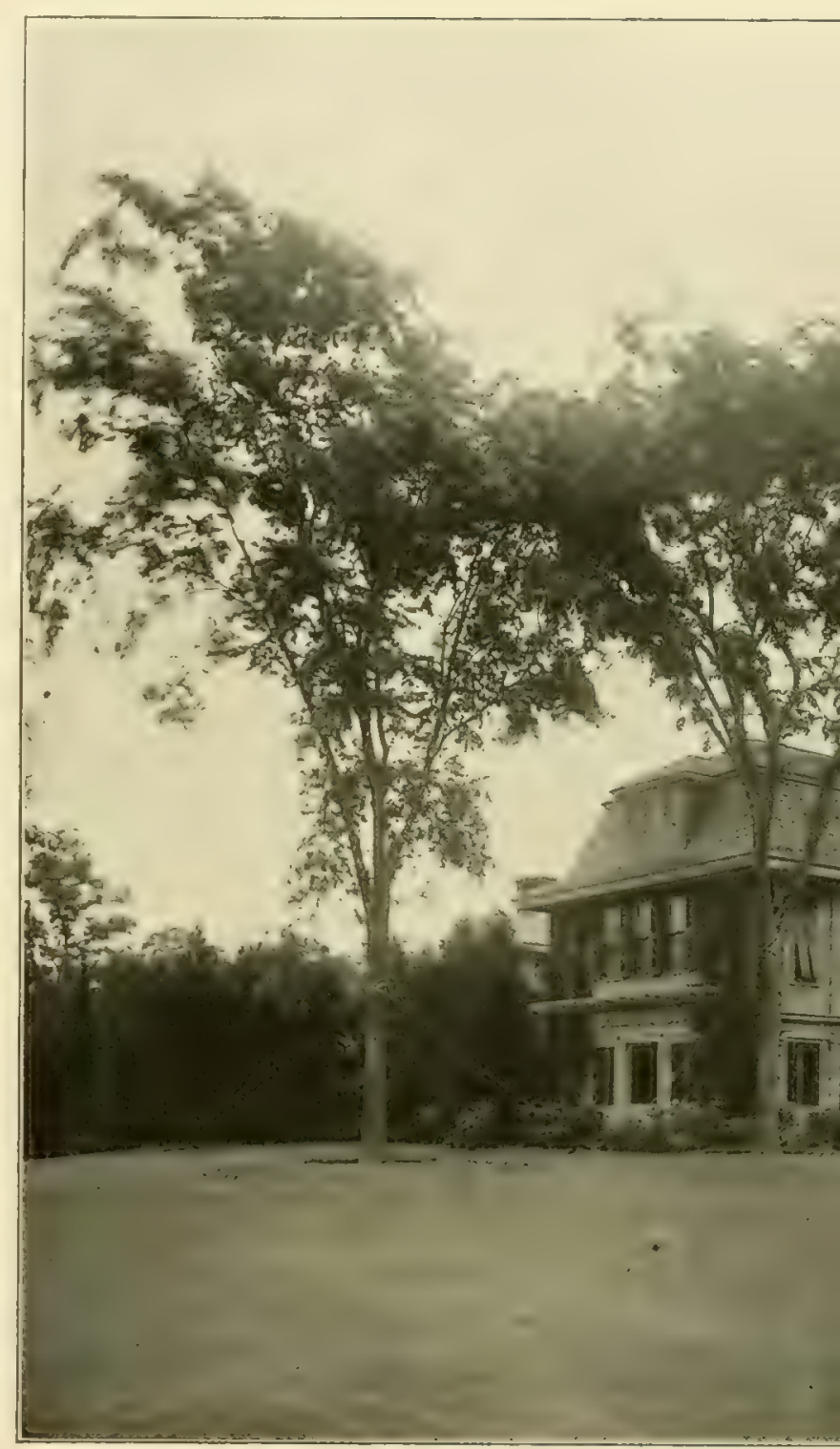

Estate of Mrs. Harold I. Pratt, showing two of the many lar planted. James L. Greenleaf, Esq., Landscape Architect. Here o moved trees large enough so their tops extend far above the hous gives the house the proper setting, yet does not shut out the vi second story nor the breeze, while providing plenty of shade. 


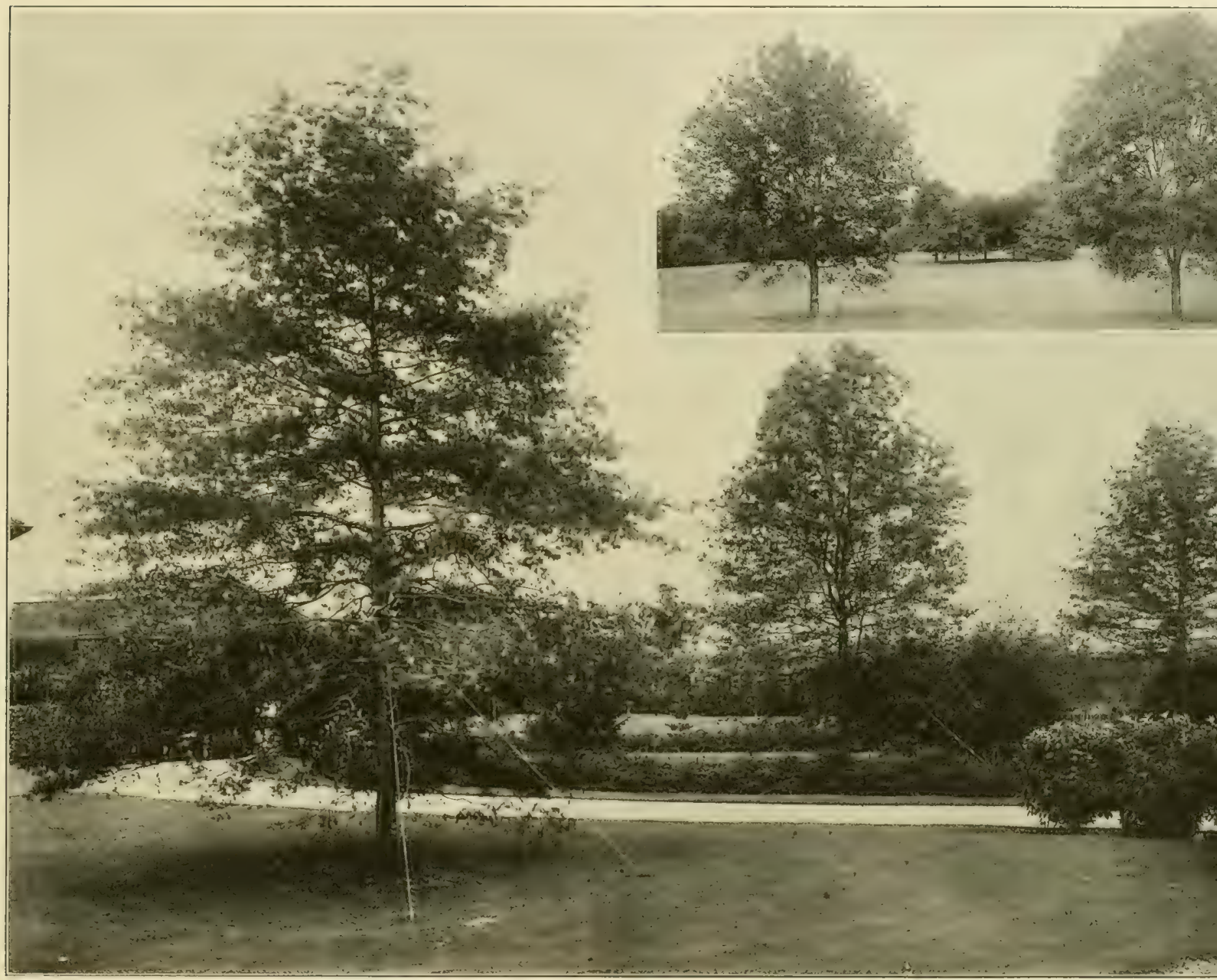

Views showing large trees planted by us on the Estate of Audley Clarke, Esq. These photographs were taken within a month after the planting Here shade was secured immediately. 


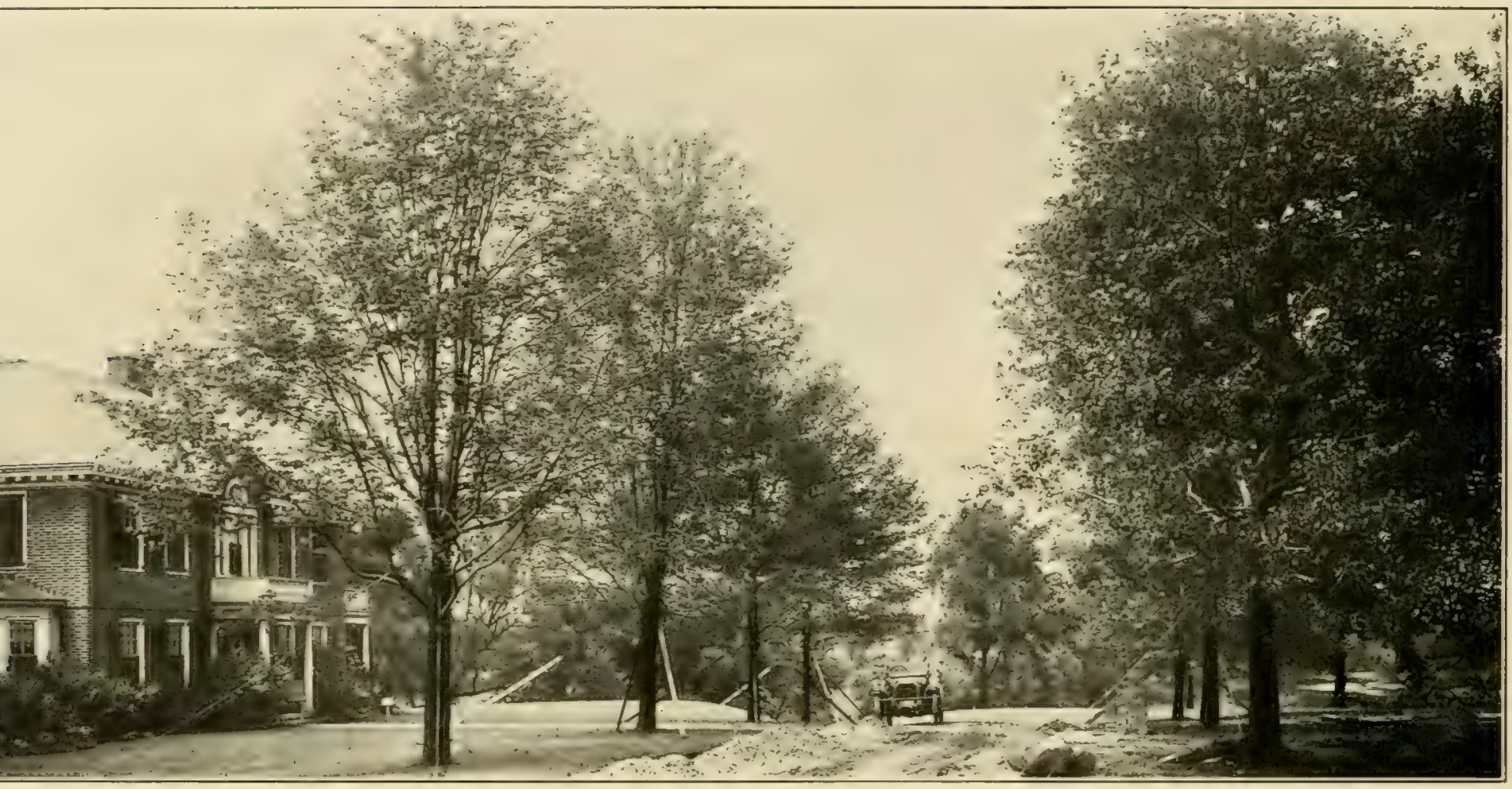

Before and after we moved for Sheffield Arnold, Esq., Landscape Architect, an avenue of very large Sugar Maples, to the grounds of the Loomis tute, Windsor, Conn. Messrs. Murphy \& Dana, Architects. Producing an immediate effect, which otherwise would have required several generaof waiting for nursery trees to grow. The expense of this work compared with the results is much less than the planting of ordinary nursery trees.

(1)


LEWIS \& VALENTINE CO.

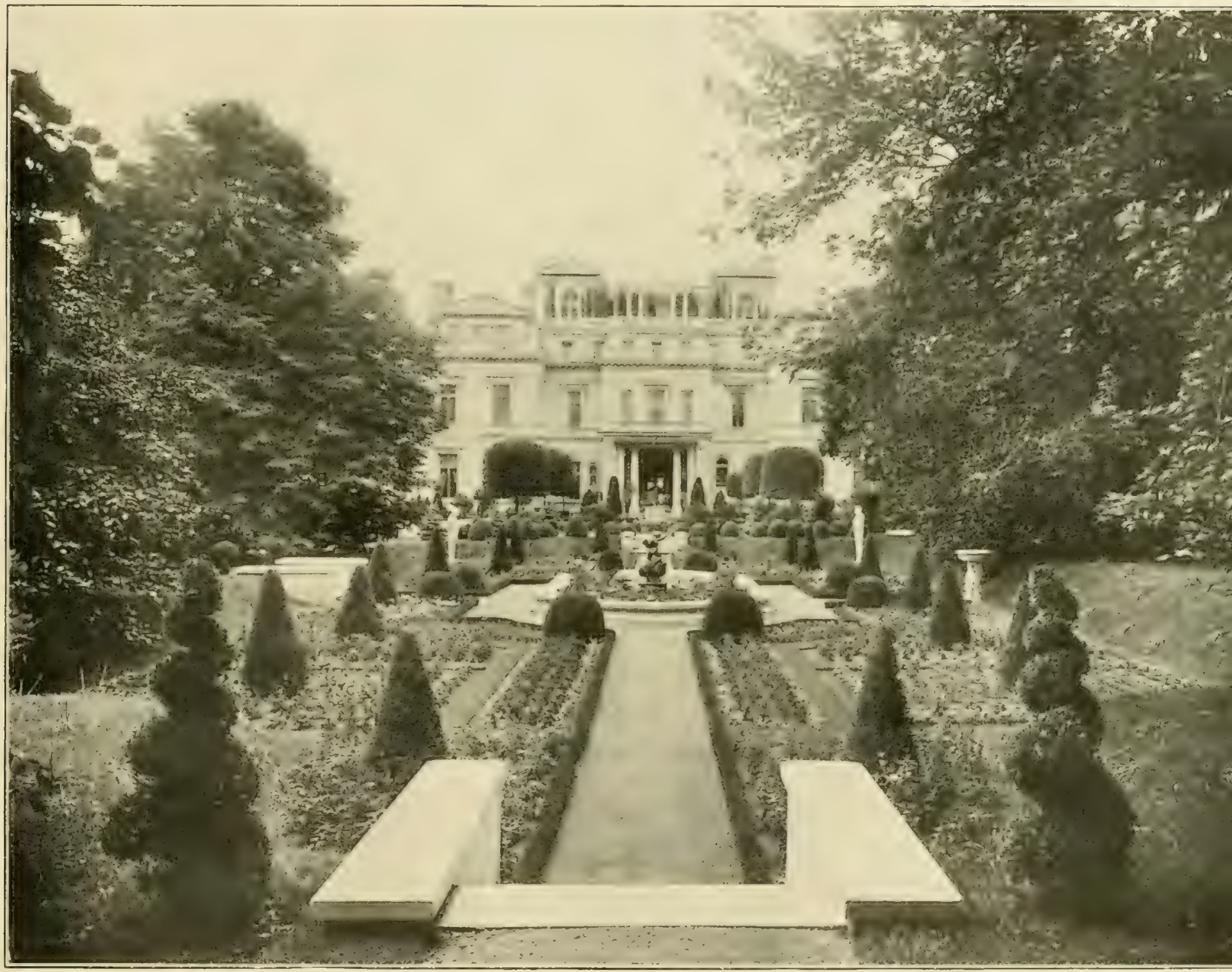

The Estate of Capt. J. R. De La Mar. To this estate we moved many large Beech, Hemlock, Elms, etc. C. P. H. Gilbert, Esq., Architect. 


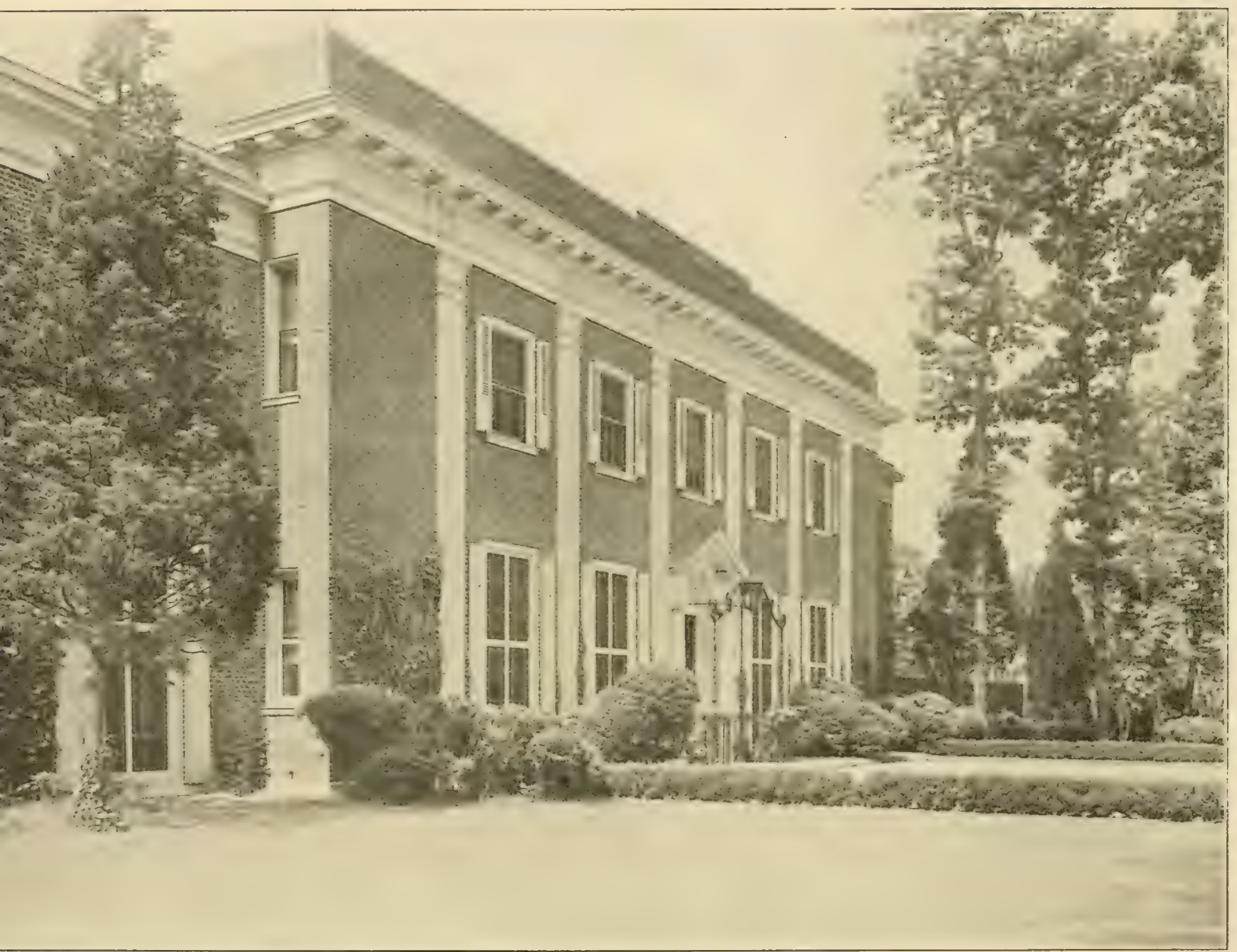

state of Mrs. Arthur Scott Burden. John Russell Pope, Esq., Architect. Large Cedars and Boxwood make a charming effect about a residence. 


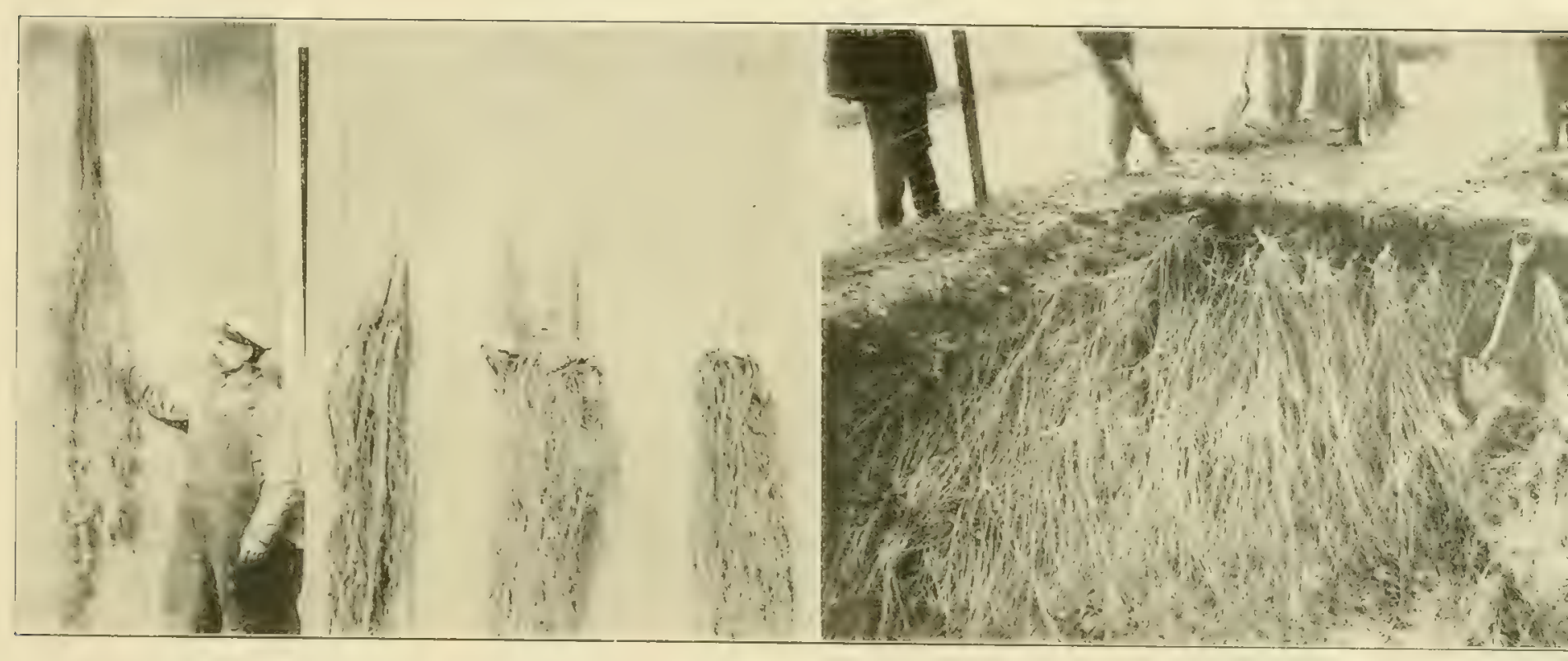

This photograph was supplied by Messrs. Olmsted Brothers, Landscape Architects. It shows the great volume of roots made within two y these trees had been dug around and new soil put about them. In many instances our large trees do better after being transplanted tha hecause the rich soil in which we plant them gives them an opportunity to make more fibrous roots, which nourish and invigorate them. 


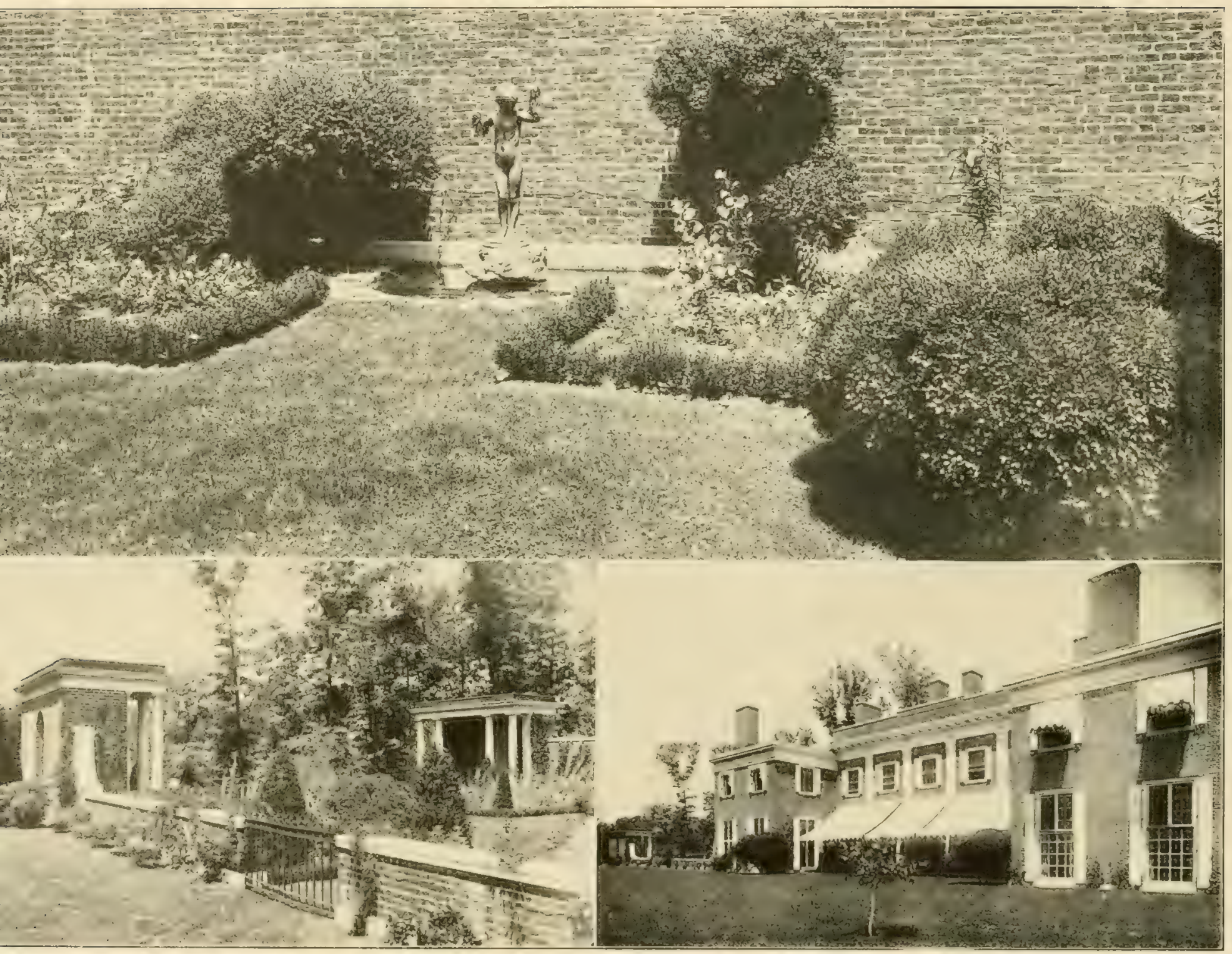

Views on the Estate of Mrs. Arthur Scott Burden, showing Boxwood and other planting, which so successfully lends the appearance of age to this wly constructed residence. John Russell Pope, Esq., Architect. Our collectors have located hundreds of large specimens of old Boxwood plants, tographs of which are on file at our office. Photographs with descriptions and prices of these will gladly be supplied. 


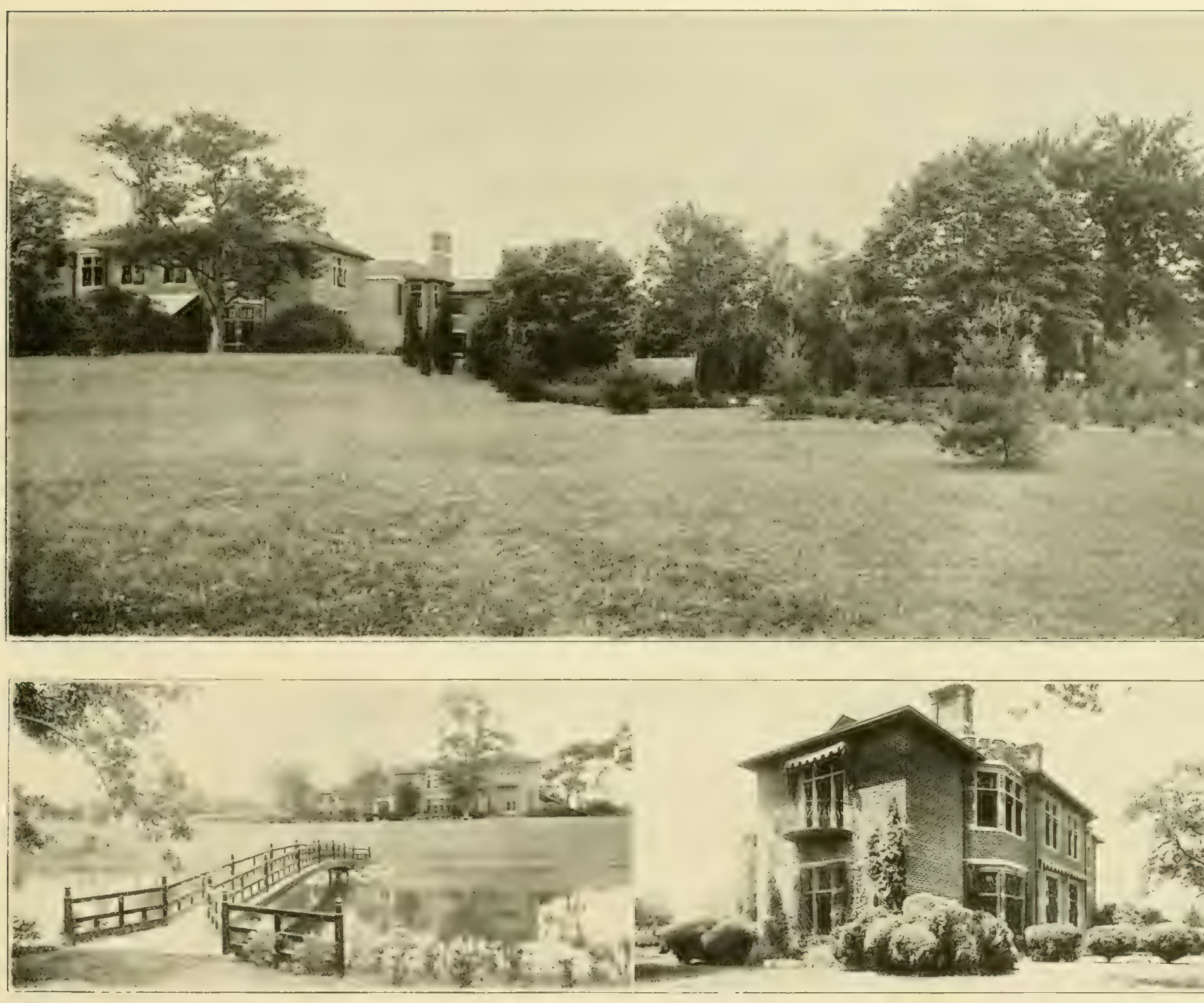

Views of the Estate of Willian K. Vanderbilt, Esq. Harold Patterson, Esq., Landscape Architect. Here we planted many large deciduous a green trees, and old Boxwood. All the trees in the upper photograph, screening the service court from the lawn were moved in the year bef Build your home where you please; then with our big trees we can screen out objectionable views immediately. 


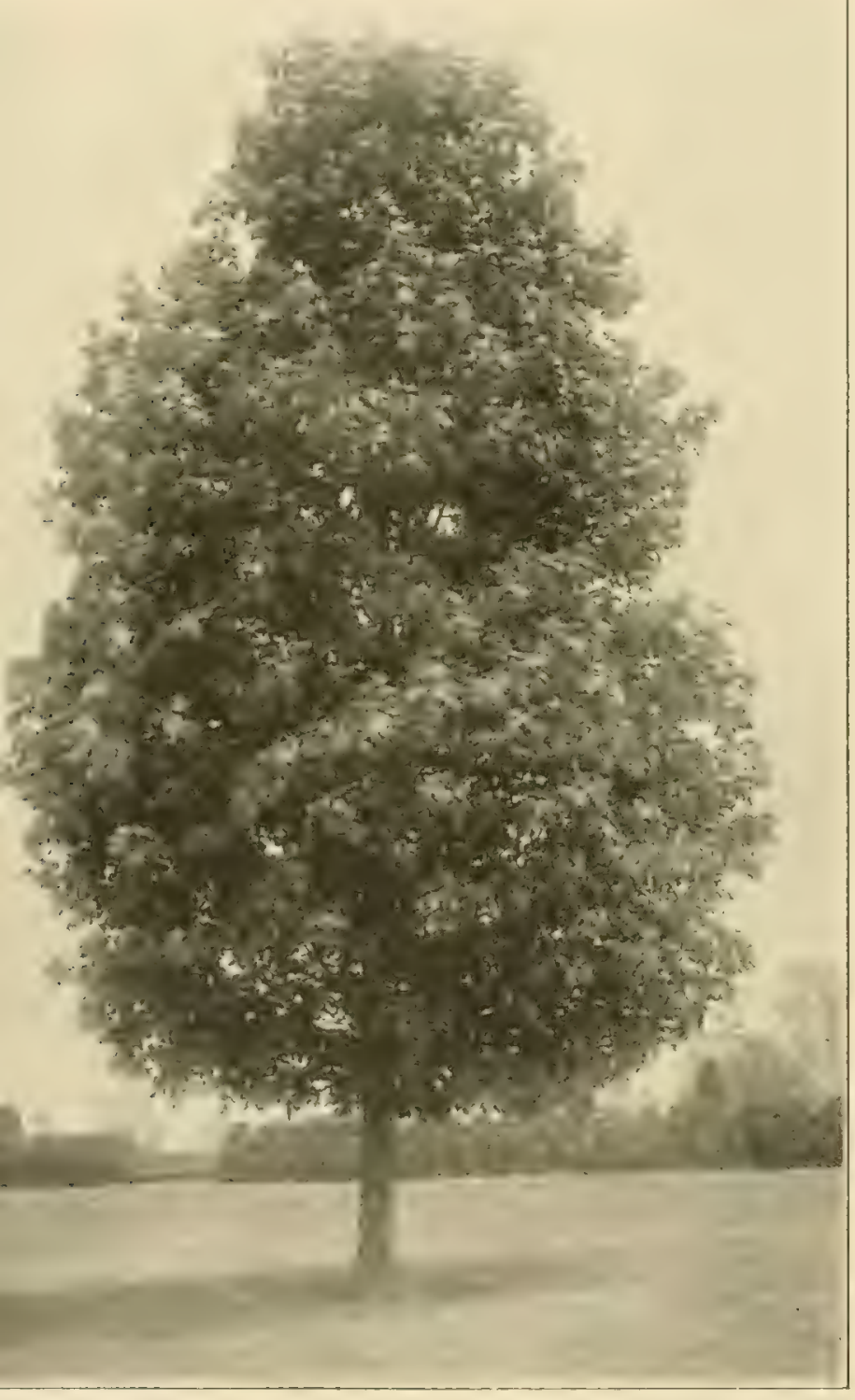

10wing some large Maples planted on the Schoonmacker Estate, at Valley. Note the vigorous growth for trees that have recently been anted.

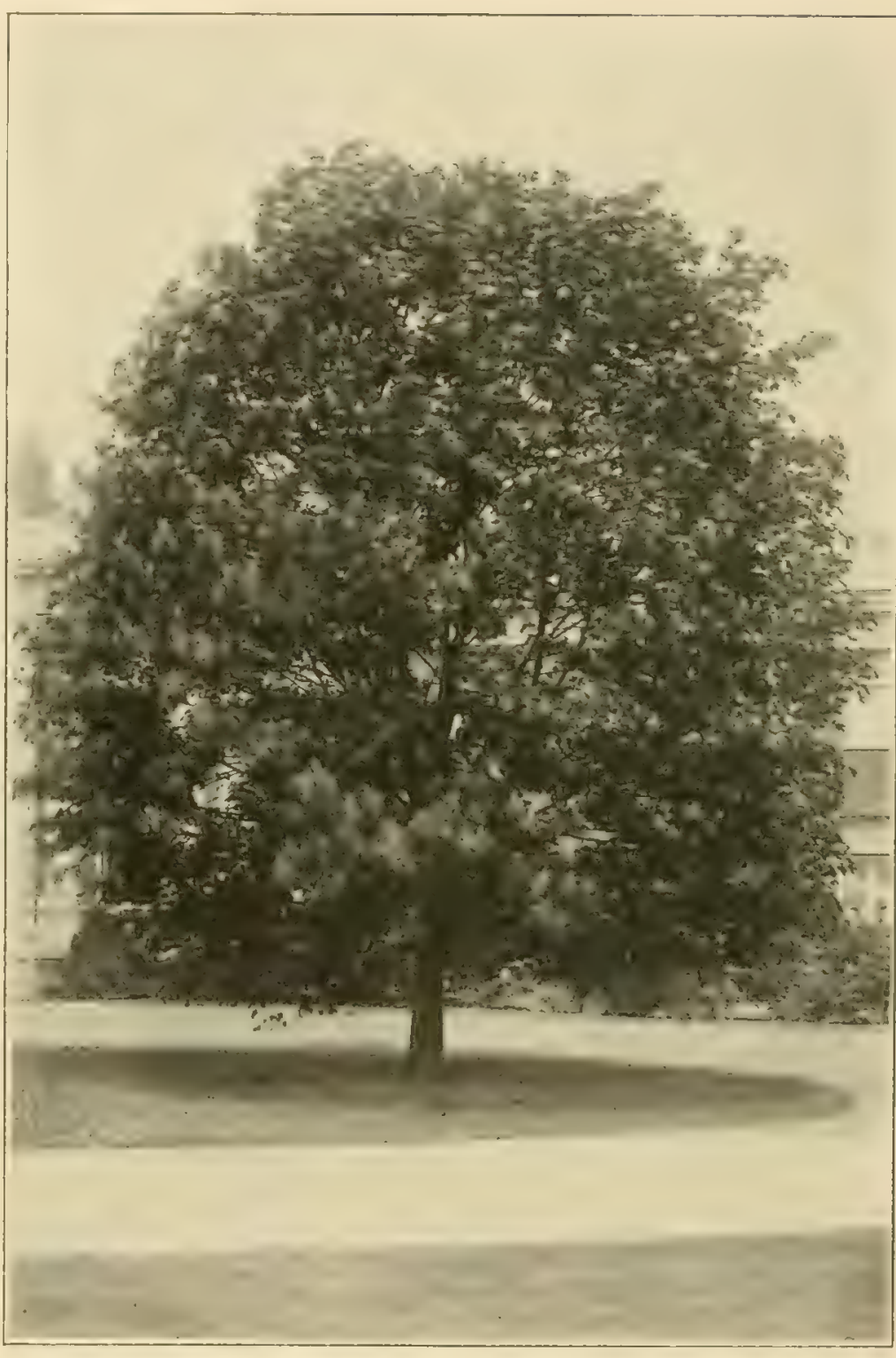

Though you build your house on a barren treeless plain, we can set a grove about it of trees up to 2 feet in diameter and from 40 to 70 feet high. 


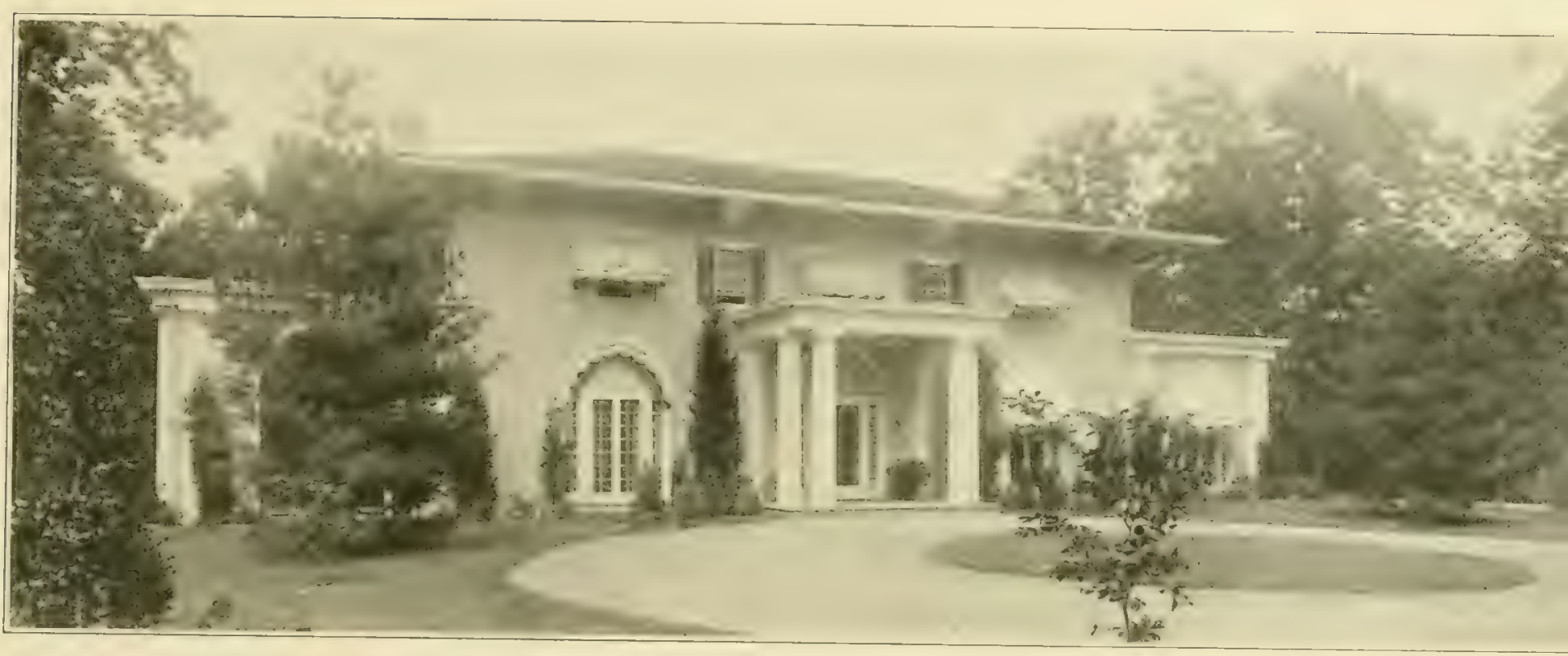

Showing a few of the large Pines and Cedars planted for Cornelius Provost, Esq., on his new Estate on Long Isiand

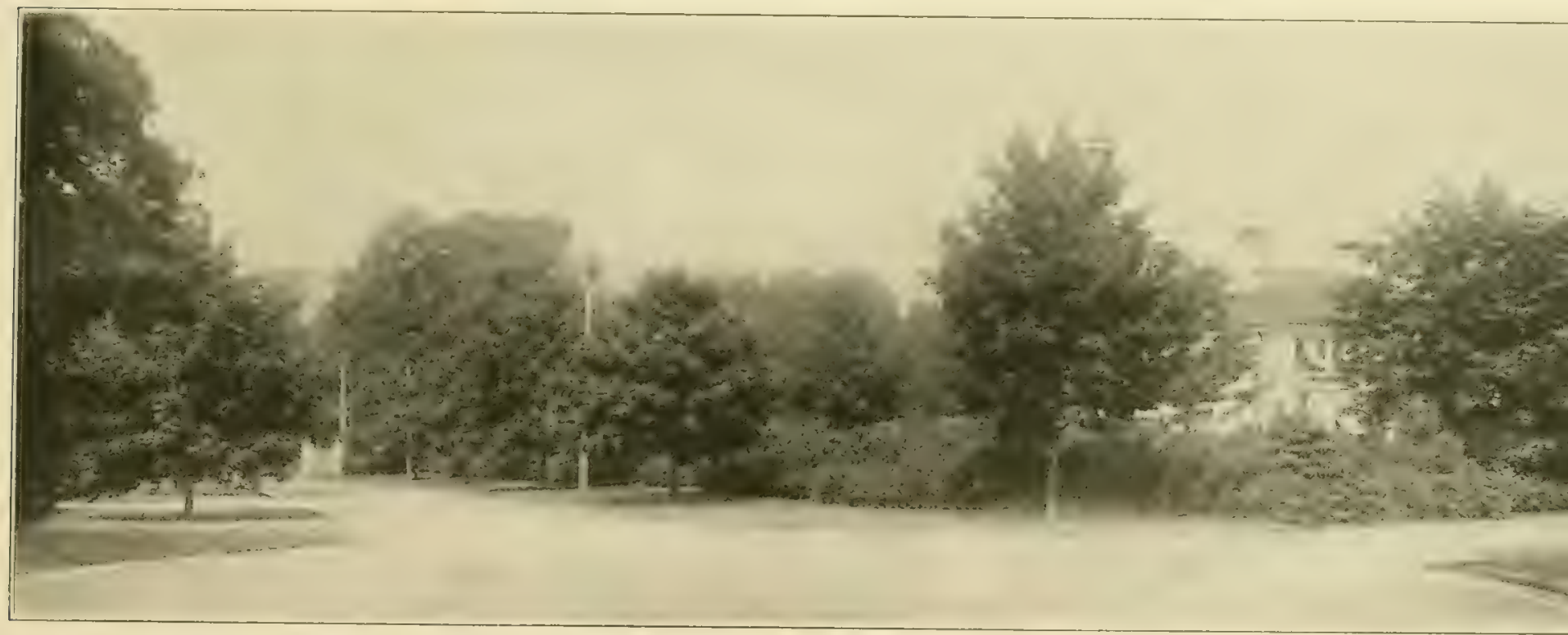

Estate of J. Stuart Blackton, Esq. Ralph N. Weinrichter, Esq., Landscape Architect. Messrs. Hoppin \& Koen, Architects. hundreds of large trees with our usual success. Note the dense foliage of the large Maples.

On this estate we t 


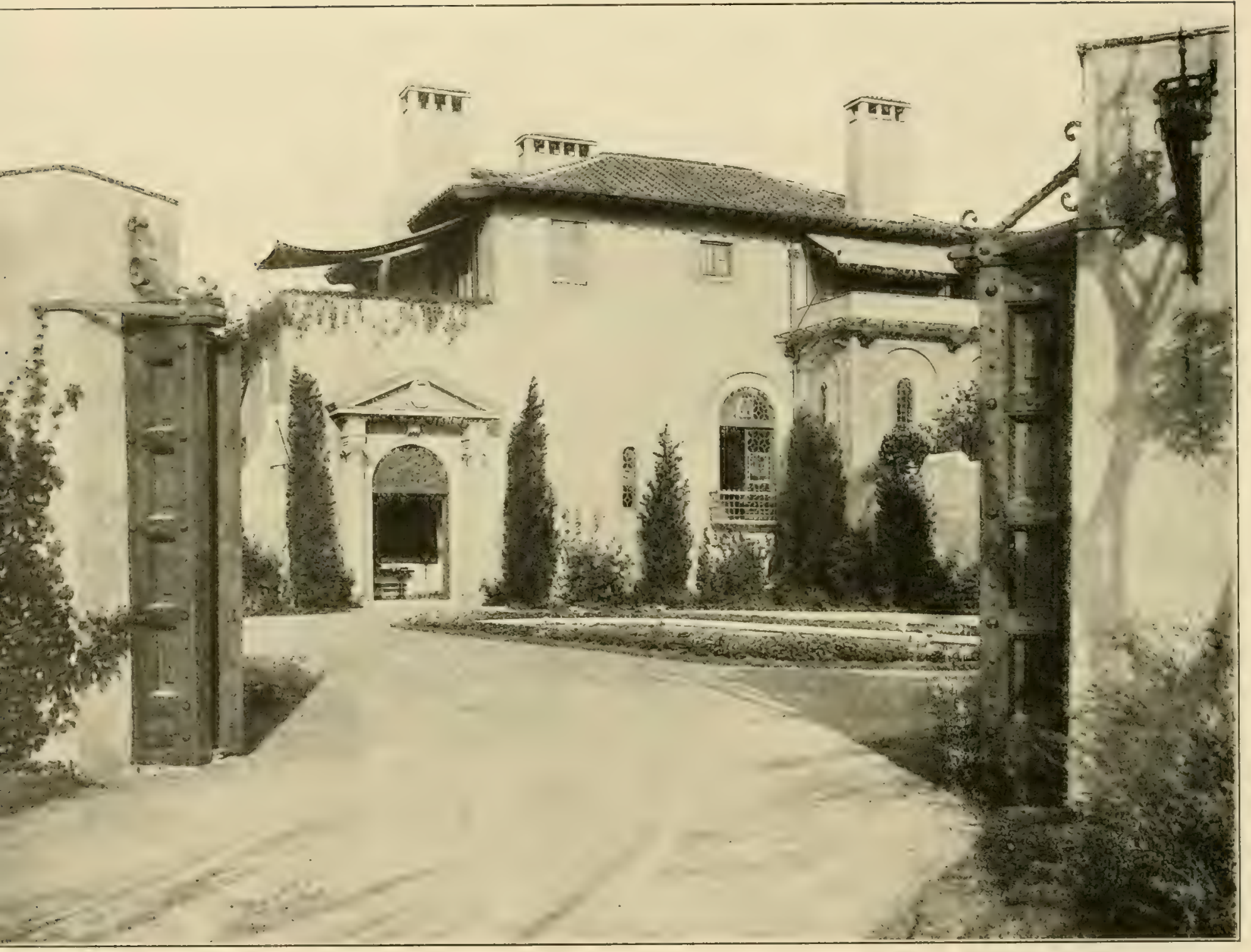

tate of H. H. Rogers, Esq., Southampton, L. I. Messrs. Walker \& Gillette, Architects. This estate was developed in one season and an immediate and mature effect was produced by using large trees moved in from the vicinity on our machines. 


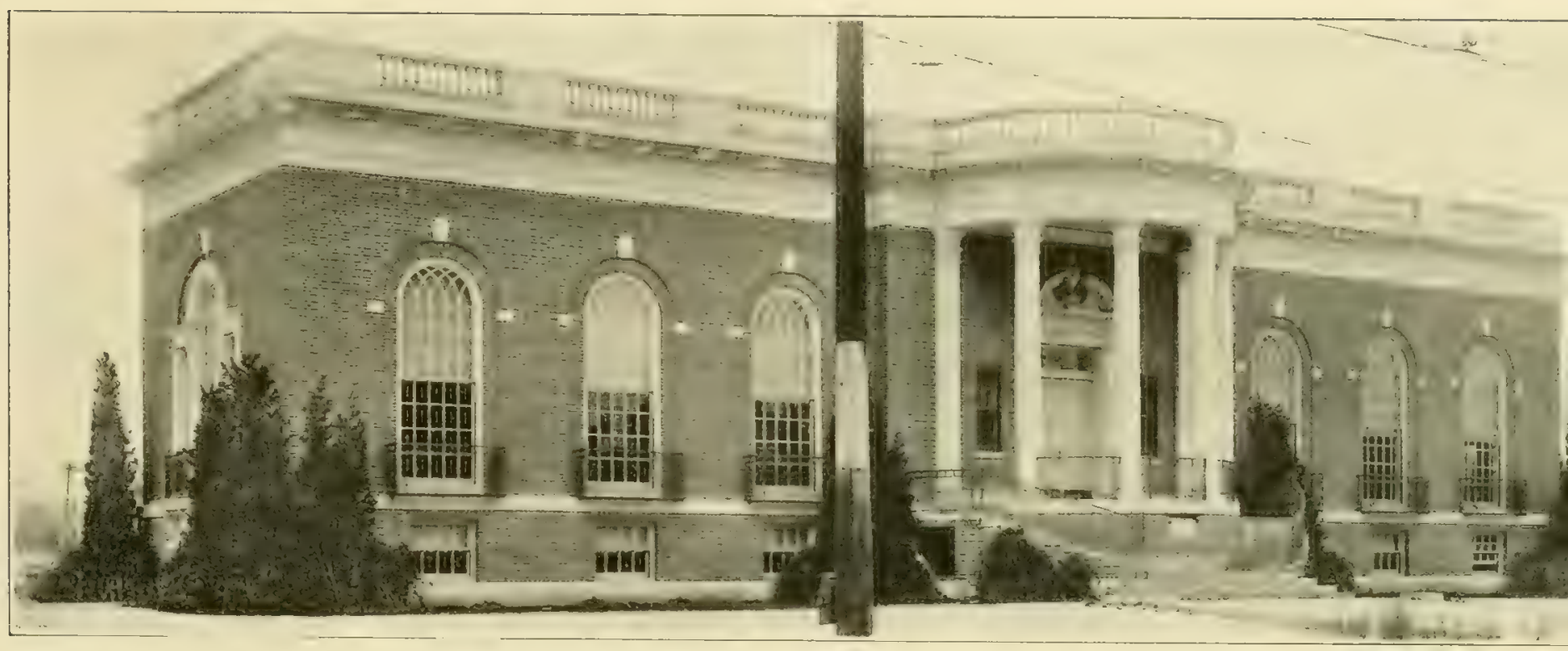

Waltham Library, Waltham, Mass. Messrs. Loring \& Leland, Architects. An immediate effect was here lproduce 1 by aj few of "our bi We have the largest supply of specimen evergreens of almost any variety, from 10 to 30 feet high. With the size of the iball'of earth on greens when we ship them, they can be safely shipped as far west as Chicago.

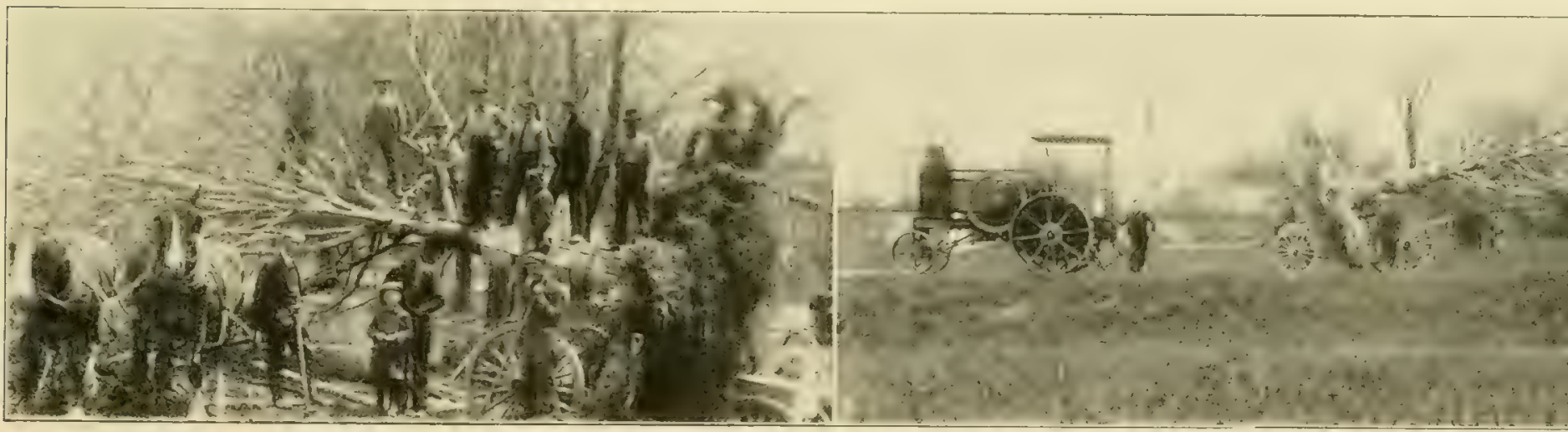

Showing how we move large Sugar Maples. Note the immense ball of earth and vast quantity of fibrous roots, protected by thick canvas, take with the tree. 


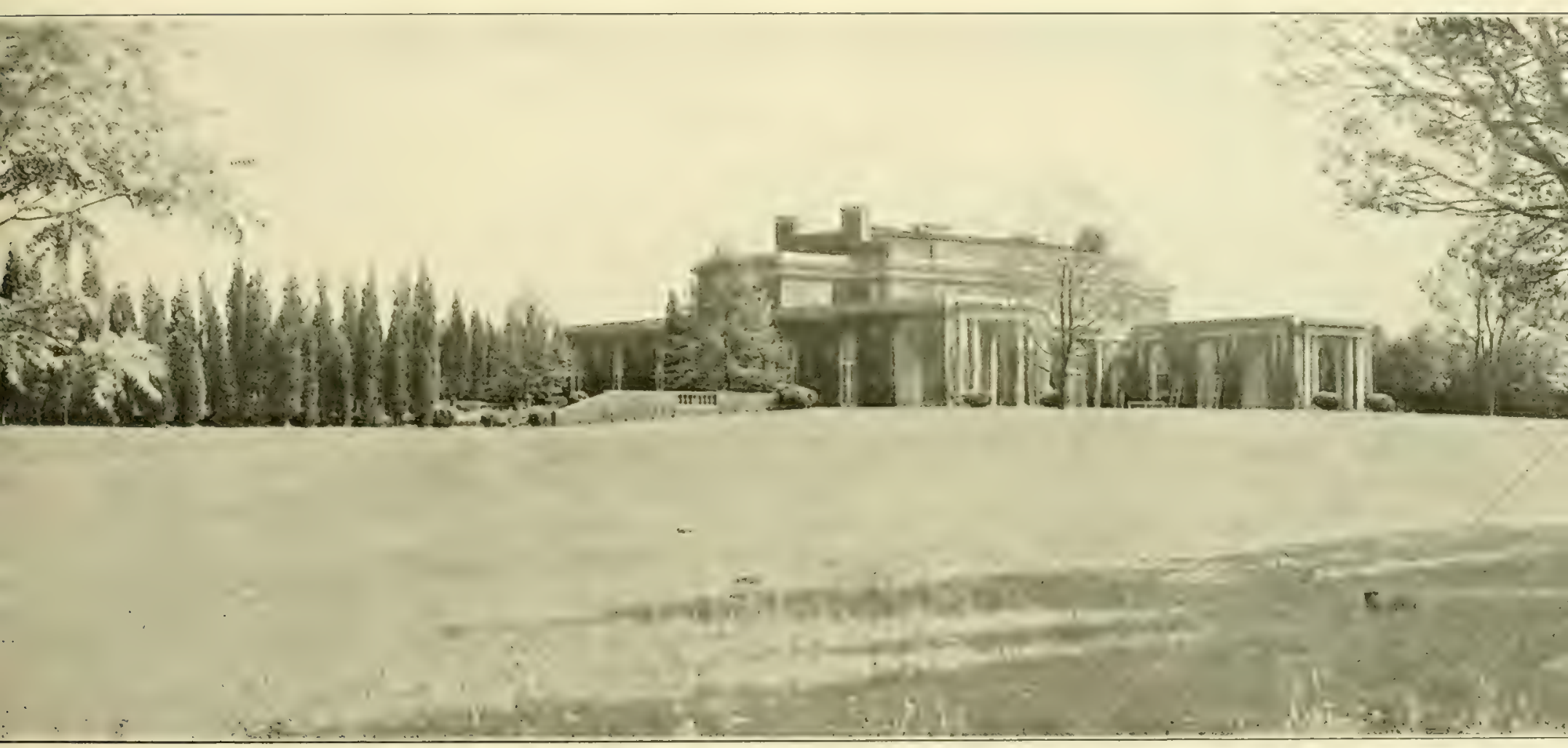

Estate of Ogden L. Mills, Esq., Woodbury, L. I., John Russell Pope, Architect. Here we moved nearly 1,000 large Cedars and many l. shade trees. It is no longer necessary to build the house in relation to the large trees, because the certainty of successful results in transplan trees as large as you want them, providing skilled labor and the proper apparatus are used. We have invented many labor saving devices in past five years that have greatly reduced the expense of big tree moving, and put it within reach of anyone who can afford the usual nursery st Big trees are, in fact, considerably cheaper than nursery stock, because a big tree, if planted at an expense of $\$ 100.00$ is less than the interes $\$ 10.00$ invested in a small tree for 40 years, and in addition to being cheaper our big trees are enjoyed by the present generation. 

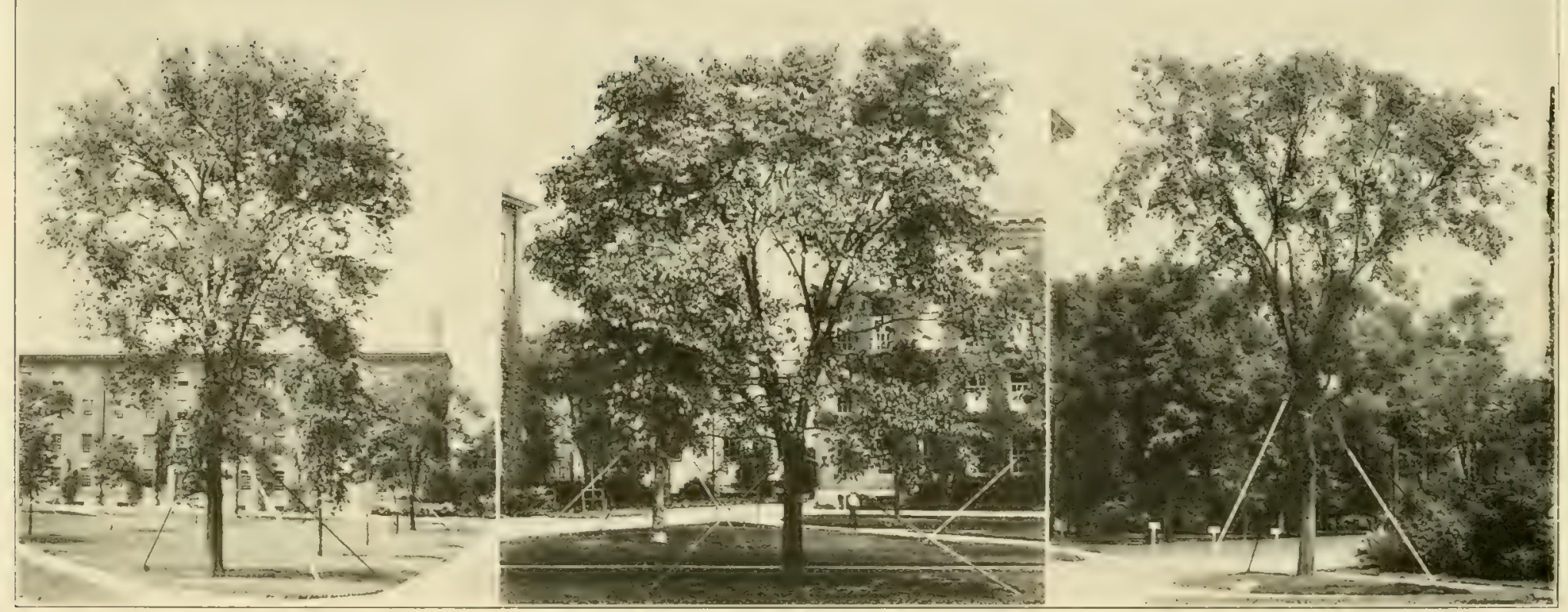

Large American Elms moved to the Harvard Yard of Harvard University on our patented tree moving machines with our trained men, producing an immediate effect, which, otherwise would have required 50 years of waiting for small trees to grow. Arthur H. Lea, Esq., of Philadelphia, presented these trees to the University and they were planted under the direction of Prof. R. F. Fisher. Note the dense growth of foliage, although these trees were moved only 3 months before photographing. These trees were moved from within a radius of 20 miles of the University grounds. 


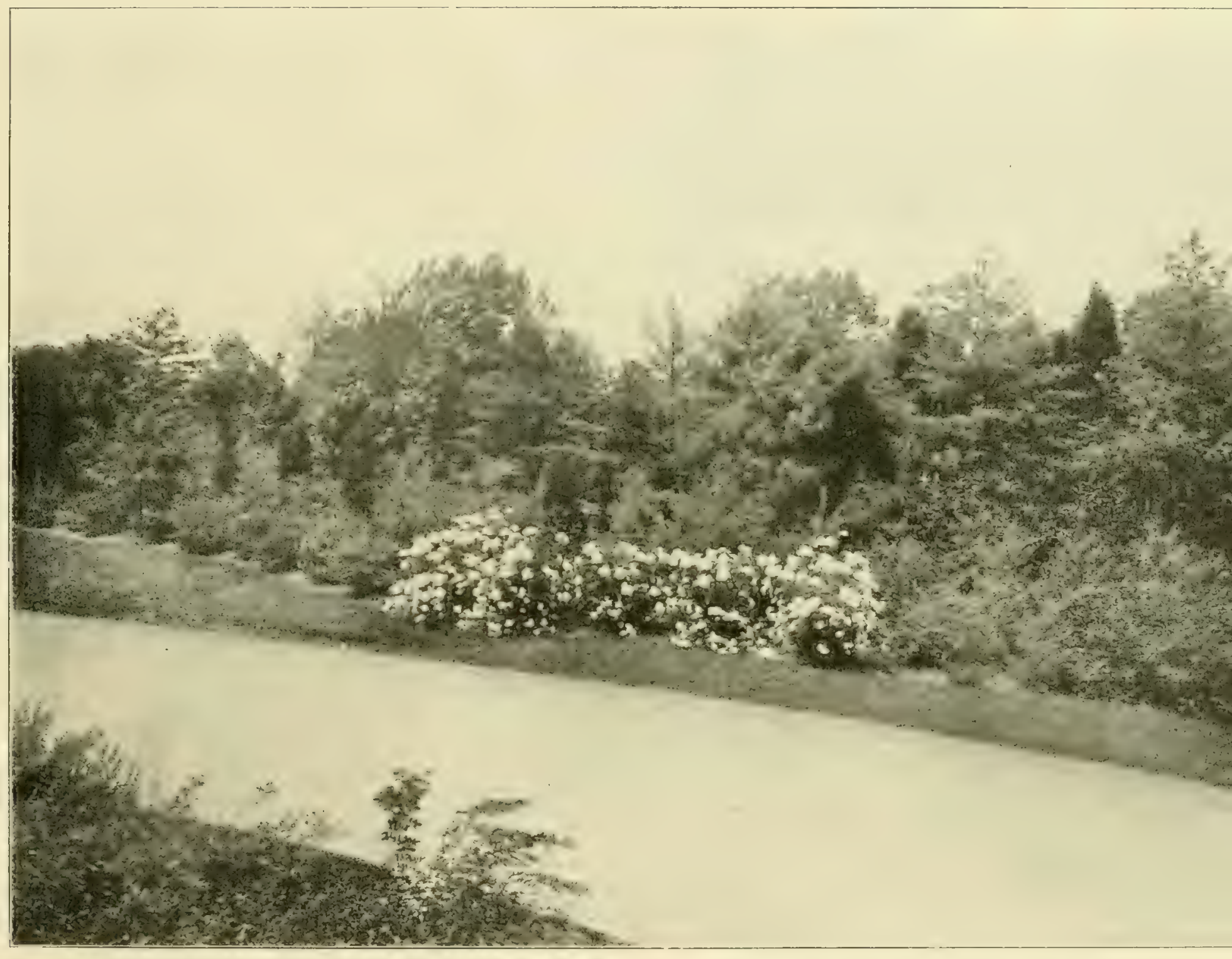

Large Pines, Cedars, Beeches, Oaks, Etc., planted as masses on the Estate of J. E. Aldred, Esqu, serving as a screen to shut out an adjoining propert Olmsted Bros., Landscape Architects 


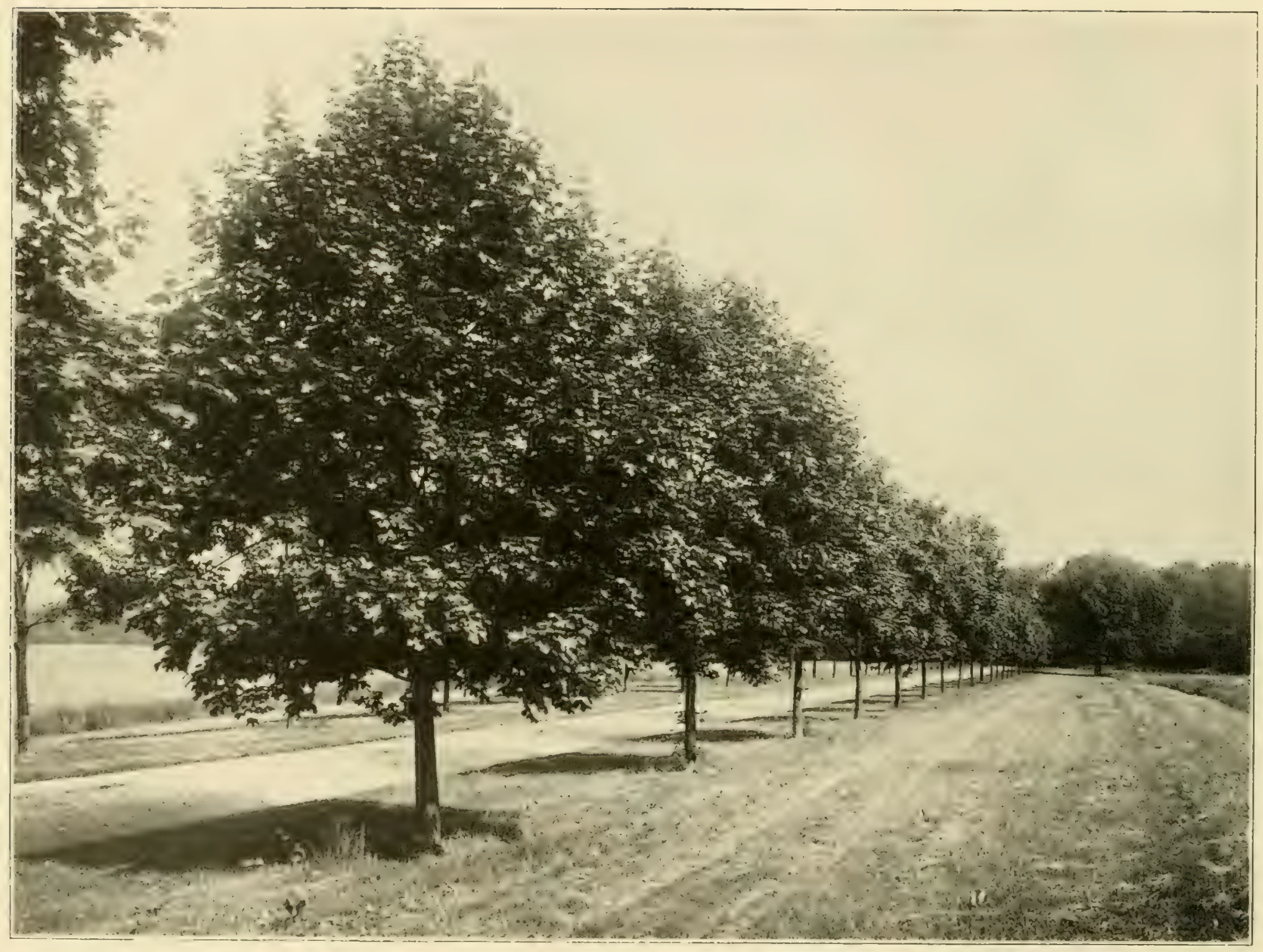

An Avenue of 25 year old Norway Maples, 30 to 35 feet high, on the estate of John G. Berquist, Esq., Brookville, L. I. Here we planted nearly 100 of these trees, producing an immediate effect. Note the dense healthy foliage-every tree in a flourishing condition. Charles Platt, Esq., Landscape Architect. We can ship trees of this size to you, by freight, in any quantity and most any variety you desire. 


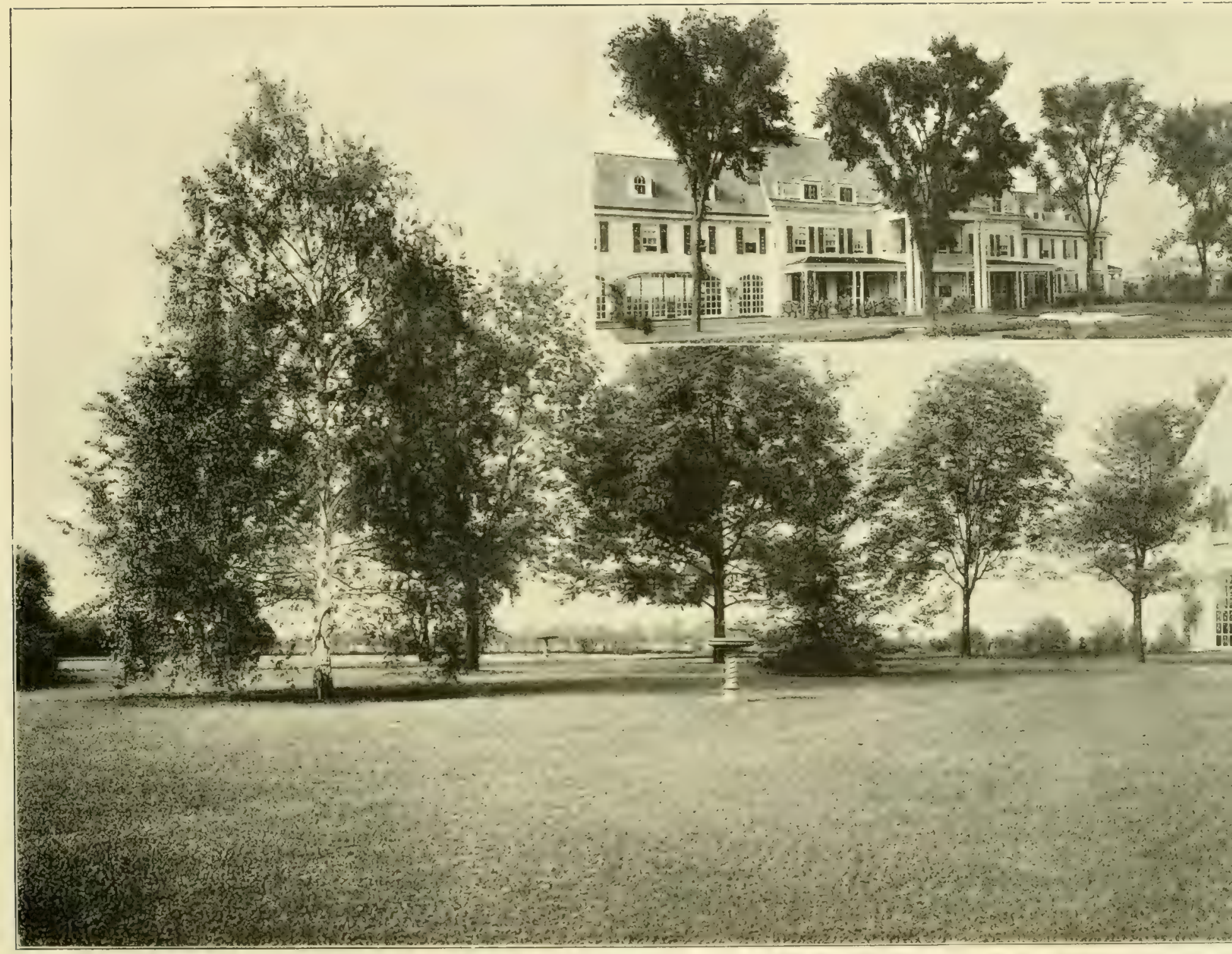

Esiate of John Anderson, Esq., Locust Valley, L. I. All the above trees were moved in by us. The lower group consists of Beech, Ash, Pin O White Birch, Holly and Maples. There is a great advantage in having a shaded area near the Residence 


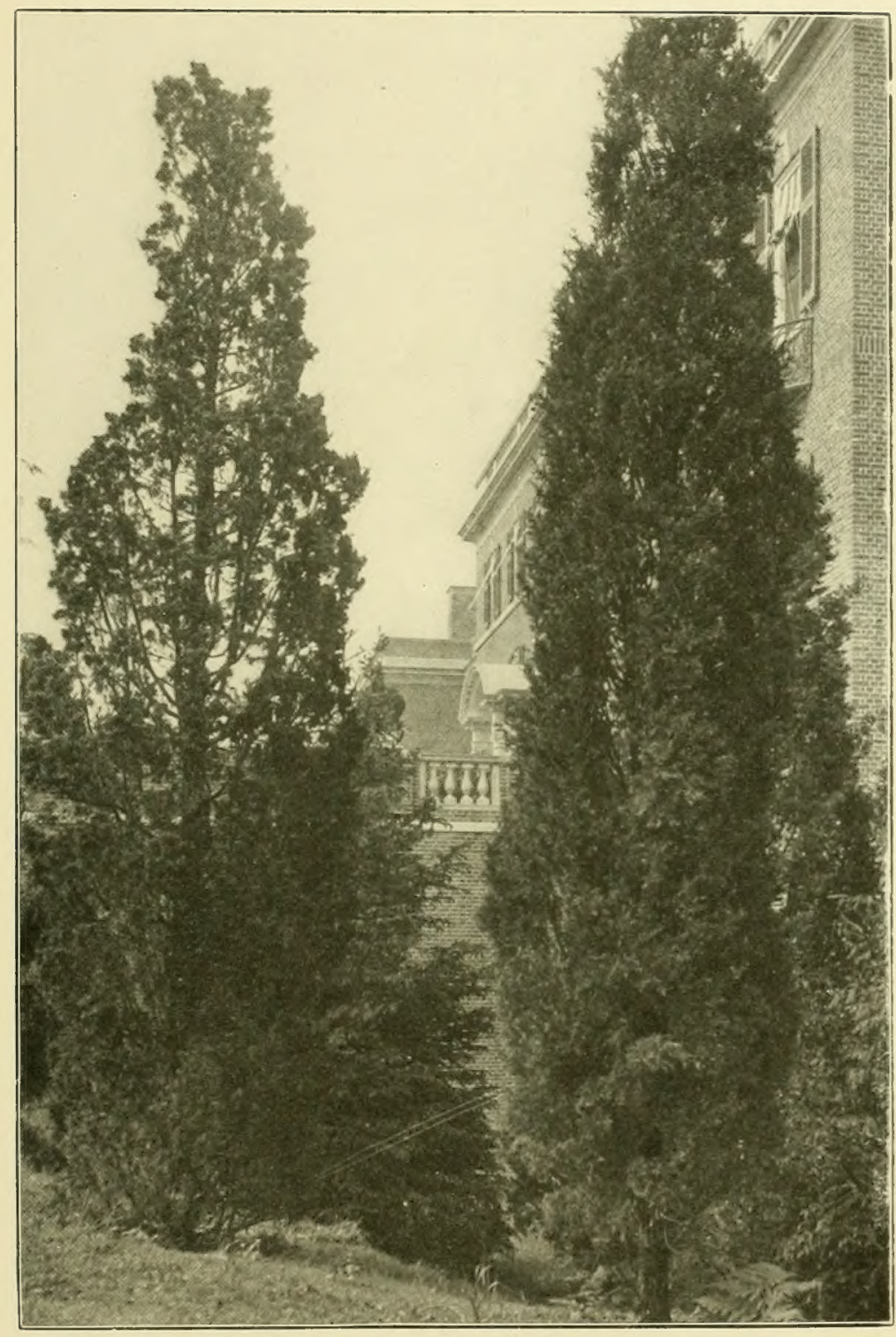

Estate of C. K. G. Billings, Esq. Landscape Architects, Guy Lowell, Esq., and A. R. Sargent, Esq. Here we moved many large Maples, Elms, Oaks, Cedars, Pines, Spruce, Hemlock, and Dogwood, producing immediate effects at a moderate expense that would have required 25 to 50 years to create with nursery trees.

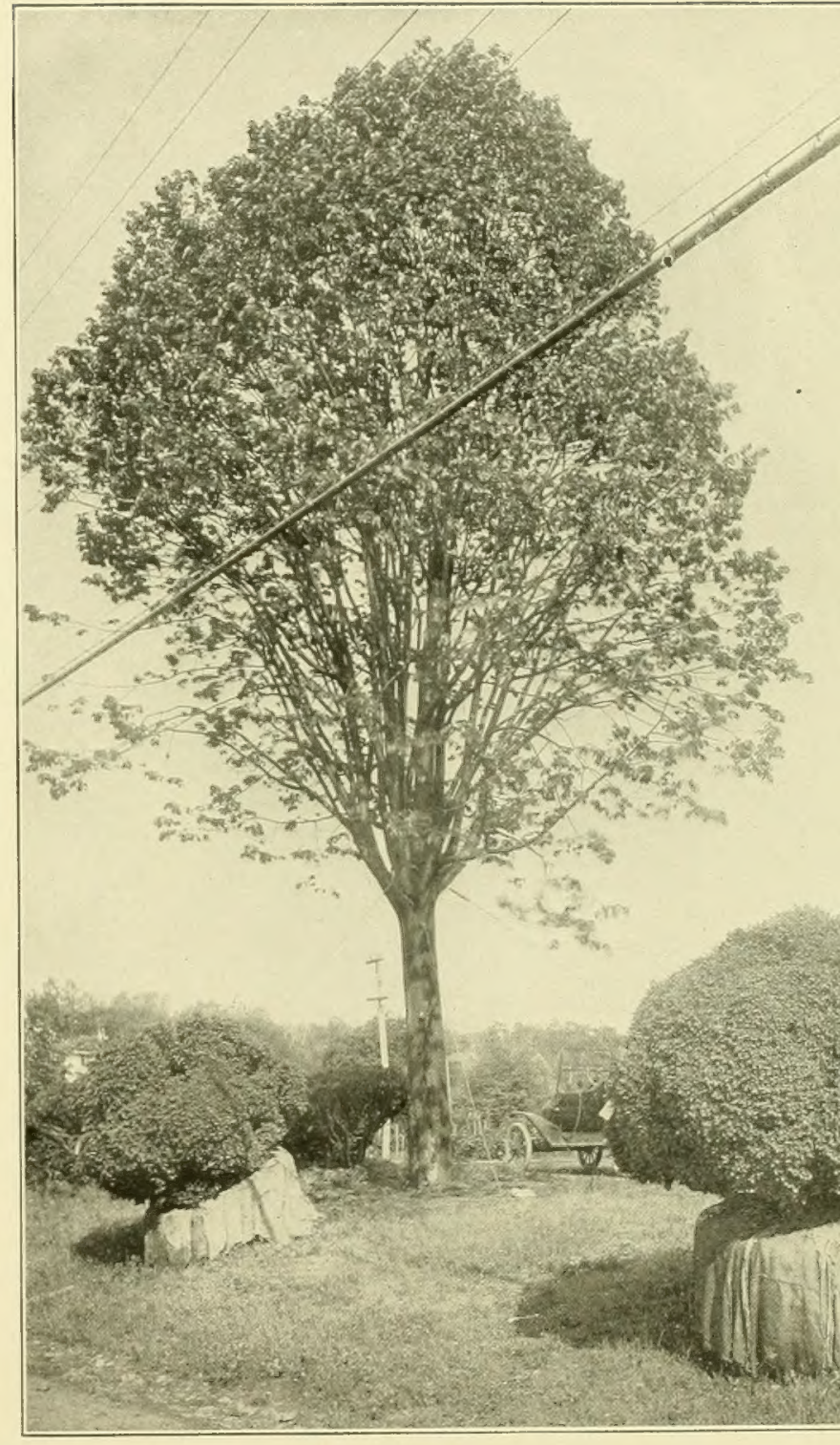

Two large Boxwood moved from our Roslyn Nursery to the Victor Morawetz, Esq. At our Roslyn nursery we have an imme of old Boxwood which we sell at moderate prices. The large Li planted last winter and is about 2 feet in diameter. Note the den for the first year. 


\section{The Following List Includes a Few of Our Customers}

nd

n Frick, Esq., Baltimore, Md. of Columbia

States Government, Washington, D. C. re

I. du Pont, Esq., Wilmington, Del. e du Pont, Esq., Greenville, Del.

S. du Pont, Esq., Wilmington, Del. .

. G. du Pont, Esq., Wilmington, Del.

ald M. J. du Pont, Esq., Montchanin, Del. . Raskob, Esq., Wilmington, Del.

ll du Pont, Esq., Montchanin, Del. harles Copeland, Wilmington, Del. rank L. Boynton, Wilmington, Del. Marvel, Esq., Wilmington, Del.

. Bissell, Esq., Wilmington, Del.

Ivania

s M. Schwab, Esq., Loretto, Pa.

rthur Biddle, Philadelphia, $\mathrm{Pa}$.

rk

ers Estate, Amsterdam, N. Y.

Hollow Country Club, Scarboro, N. Y. an.Wanamaker, Esq., Tuxedo Park, N.Y. ticut

Lockwood, Esq., Riverside, Conn.

s Institute, Windsor, Conn.

in F. Plant, Esq., New London, Conn.

e Landers, Esq., New London, Conn.
LANDSCAPE ARCHITECTS

J. Russell Pope, Esq.

Messrs. Carrere \& Hastings H. T. Lindeberg, Esq.

I Ferruccio Vitale, Esq. , Clarence Fowler, Esq.

Ferruccio Vitale, Esq. Clarence Fowler, Esq.

( Ferruccio Vitale, Esq. Clarence Fowler, Esq.

R. B. Cridland, Esq.

C. W. Leavitt, Esq.

( Ferruccio Vitale, Esq. Clarence Fowler, Esq.

$\int$ Ferruccio Vitale, Esq. Clarence Fowler, Esq. Sheffield, Arnold Esq. f Guy Lowell, Esq. \{ A. R. Sargent, Esq. ( Guy Lowell, Esq. \{ A. R. Sargent, Esq.

\section{Massachusetts}

Waltham Library, Waltham, Mass.

Harvard University, Cambridge, Mass.

M. E. Madden, Esq., Newton, Mass.

E. W. Shraft, Esq., Winchester, Mass.

\section{Long Island}

Pratt Estates, Glen Cove, L. I.

C. V. Brokaw, Esq., Glen Cove, L. I.

C. K. G. Billings, Esq., Glen Cove, L. I.

O. G. Smith, Esq., Centre Island, Oyster Bay, L. I.

O. L. Mills, Esq., Woodbury, L. I.

J. E. Aldred, Esq., Glen Cove, L. I.

Henry Sanderson, Esq., Locust Valley, L. I.

Dr. P. P. Satterwhite, Great Neck, L. I.

Mrs. W. K. Vanderbilt, Sr., Jericho, L. I.

H. B. Hess, Esq., Huntington, L. I.,

Mrs. Frederick Baker, Southampton, L. I.

E. W. C. Arnold, Esq., Babylon, L. I.

J. R. DeLamar, Esq.,

George C. Smith, Esq.

Mrs. Frederick L. Richards

Bradley Martin, Esq.

H. H. Rogers, Esq.

Victor Morawetz, Esq.

William Thaw, Esq.

C. A. Coffin, Esq.

George F. Baker, Jr., Esq.
LANDSCAPE ARCHITECTS

Messrs. Loring \& Leland

Prof. R. F. Fisher

Prof. H. V. Hubbard

Sheffield Arnold, Esq.

James L. Greenleaf, Esq.

Messrs. Movius \& Roach

Guy Lowell, Esq.

A. R. Sargent, Esq.

Ralph N. Weinrichter, Esq. John Russell Pope, Esq.

Messrs. Olmsted Brothers

Messrs. Olmsted Brothers

Messrs. Olmsted Brothers

Harold Patterson, Esq.

Messrs. Howells \& Stokes

Messrs. Hiss \& Weeks

Prentice Sanger, Esq.

C. P. H. Gilbert, Esq.

C. W. Leavitt, Jr., Esq.

William Adams, Esq.

Messrs. Carrere \& Hastings Messrs. Walker \& Gillette

Messrs. Delano \& Aldrich

( Guy Lowell, Esq.

A. R. Sargent, Esq.

Messrs. Olmsted Brothers

\section{LEWIS \& VALENTINE COMPANY, Roslyn, N. Y.}

Offices: 722 French St., Wilmington, Delaware, C.C. Clifton Lewis, Manager. Brookline, Massachusetts, Geo. N. Barrie, Manager 


\section{A Few of Our Customers - (Continued)}

\section{Long Island}

A. G. Milbank, Esq., Huntington, L. I. Rober Hager, Jr., Esq., Oyster Bay, L. I. Mrs. C. C. Rumsey, Wheatley Hills, L. I. Mrs. Arthur Scott Burden, Jericho, L. I.

W. R. Coe, Esq., Oyster Bay, L. I.

Guernsey Curran, Esq., Oyster Bay, L. I. .

J. Stuart Blackton, Esq., Oyster Bay, L. I. Otto H. Kahn, Esq., Woodbury, L. I. .

Bronson Winthrop, Esq., Wheatley Hills, L. I. Geo. E. Fahys, Esq., Locust Valley, I. I. , Montague Flagg, 2nd, Esq., Brookville, L. I. John G. Berguist, Esq., Brookville, L. I.

E. Mortimer Barnes, Esq.; Glen Head, L. I. H. L. Batterman, Esq., Mill Neck, L. I. A. Z. Gray, Esq,, Wheatley Hills, L. I. Richard N. L. Church, Esq, Great Neck Alan Corey, Esq., Glen Head, L. I.

Herbert Harriman, Esq., Jericho, L. I. William H, Van der Poel, Esq.; East Norwich, L. I.

John J. Watson, Jr., Esq., Brookville, L. I. .

\section{ARCHITECTS \\ AND LANDSCAPE ARCHTTECTS}

Messrs. Howells \& Stokes W. Prentice Sanger, Esq. Messrs. Movius \& Rotch John Russell Pope, Esq.

(Messrs. Guy Lowell, Esq A. R. Sargent, Esq.

Messrs. Guy Lowell, Esq. $\{$ A. R. Sargent, Esq.

Ralph N. Weinrichter, Esq. Messrs. Delano \& Aldrich Messrs. Delano \& Aldrich Jas. W. O'Connor, Esq. Montague Flagg, 2nd, Esq.

Thos. H. Ellett, Esq. H. T. Lindeberg, Esq. F. B. Martin, Esq. Ralph N. Weinrichter, Esq. Montague Flagg, 2nd, Esq.

Messrs. Cross \& Cross

F. B. Martin, Esq.

\section{Long Island}

Acosta Nichols, Esq., Oyster Bay, L. I.

Thomas Hastings, Esq., Old Westbury, L. I. Mrs. William Beard, Glen Cove, L. I. . . . Mrs. J. Sargent Cram, Wheatley Hills, L. I. E. J. Stehli, Esq., Locust Valley, L. I. A. H. Cosden, Esq., Southold, L. I. . Mrs. Henry C. Phipps, Sr., Great Neck, L. I. Mrs. William Pell, Garden City, L. I. .

F. S. Von Stade, Esq., Westbury, L. I. Anson W. Burchard, Esq., Locust Valley, L. I. Nicholas F. Brady, Esq., Roslyn, L. I. . . . Henry W. Lowe, Esq., Wheatley Hills, L. I. Cornelius Provost, Esq., Brookville, L. I. Mrs. Donald Geddes, Glen Cove, L. I. John Anderson, Esq., Locust Valley, L. I. George S. Brewster, Esq., Elast Norwich, L. I. Mrs. Egerton L. Winthrop, Jr., Syosset, L. I. Joseph P. Grace, Esq., Manhasset, L. I. . Bruce Clark, Esq.; Glen Cove, L. I. Hon. Townsend Scudder, Glen Cove, L. I. AND LANDSCA

Messis. Guy ] A. R. Sargent

Thomas Hast (1)

James L. Bur Messrs. Olmst

Messrs. Cross Alfred Hopkir John Windrur John Russel I

James L. Gre

Arthur A. Shu

\section{LEWIS \& VALENTINE CO, Roslyn, N. Y.}

Branch Offices: C. Clifton Lewis, Manager, 722 French St., Wilmington, Delaware. Geo. N. Barrie, Manager, Brookline, Ma 150 Nassau Street, New York 


\title{
LEWIS \& VALENTINE CO.
}

\author{
ROSLYN, LONG ISLAND
}

